(C) The Pakistan Development Review

48 : 4 Part II (Winter 2009) pp. 885-920

\title{
A Dynamic Analysis of the Relationship among Human Development, Exports and Economic Growth in Pakistan
}

\author{
Muhammad Afzal, A. Rauf Butt, HafeEz ur ReHMan, and Ishrat Begum
}

\section{INTRODUCTION}

Human Development (HD), being the ultimate objective of each and every human activity, plays a vital role in producing high skilled manpower that leads to economic growth and hence economic development. "HD denotes both the processes of widening people's choices and level of their achieved well being" [UNDP (1990), p.10]. HD is the enlargement of people's choices to live more prosperous lives. Economists consider HD as one of the most important ingredients of economic growth. Two periods regarding growth theories are very important in economic literature. In the first period, i.e. in late 1950s and 1960s, physical capital (PC) was given too much role in explaining economic growth but long run economic growth can be explained only by assuming an exogenous technological progress. In the second period, i.e., late 1980s and early 1990s, economic growth models were extended by inclusion of human capital (HC) and thereby endogenous growth theories emerged [Romar (1986, 1987, 1990); Lucas (1988); Grossman and Helpman (1991); Rebelo (1991)]. Human capital is endogenous here and growth rate may continue to rise because returns on investments in human capital do not necessarily exhibit diminishing marginal returns. Human capital accumulations as an endogenous factor proved to be the main contributor in explaining sustainable long run economic growth. There are two main approaches through which human capital is likely to affect the long-run economic growth. The first approach known as 'Lucasian' [Lucas (1988)] incorporates human capital into growth model as one of the factor of production. The second approach called 'Romerian' [Romer (1990)] depends upon the idea that human capital promotes technological advancement. According to Romerian approach, high level of human capital results in more innovation and more efficiency of the work force that, in turn, leads to more growth in aggregate income. This paper utilises Lucasian approach. While explaining endogenous growth theory, Lucas (1988), Romer (1990) and Grossman and Helpman (1991) have argued that either human capital or trade is main

Muhammad Afzal<muhammad_afzalch@yahoo.com> is Lecturer, Department of Economics, University of the Punjab, Lahore. A. Rauf Butt <drarbutt@yahoo.com> is Professor, School of Business and Economics, University of Management and Technology, Lahore. Hafeez ur Rehman <dehrehmankhan@gmail.com> is Associate Professor/Chairman, Department of Economics, University of the Punjab, Lahore. Ishrat Begum <ask4ishratbegum@gmail.com> is Lecturer in Political Science, Queen Marry College, Lahore. 
source of economic growth. Exports, being the important part of trade, are considered as important ingredient of progress and prosperity of both developed and developing nations.

A number of studies in literature are available that have examined the "export-led economic growth hypothesis' and 'growth-driven exports hypothesis' [e.g. Shan and Sun (1998); Ahmad (2001); and see Afzal, Rehman and Rehman (2008), for reference of more recent studies). There also exists a vast literature on the linkage between human capital and economic growth. Economic growth and hence economic development cannot be sustained unless and until preceded by improvements in $\mathrm{HD}$. If $\mathrm{HC}$ is a prerequisite for sustainable economic growth, the government as well as private funding must be allocated in such a way that help move a nation above a threshold level of HD. 'Exportled growth hypothesis' postulates that exports actively lead to economic growth in the following manner. Firstly, export promotion incentives and schemes directly encourage the exporters to produce more exportables. This, in turn, leads to specialisation and to get fruits of the economies of scale and country's comparative advantage. Secondly, increased exports may help the country to import high value inputs, products and technologies that, further, may have a positive impact on economy's overall productive capacity. 'Growth-driven export hypothesis' postulates that growth leads to exports. Economic growth itself promotes trade flows. It also leads to specialisation and creates comparative advantage in a certain areas that further facilitates exports. So there may or may not exit a bidirectional linkages between economic growth and exports.

Bivariate causality framework between economic growth and exports excludes some other most relevant economic and non-economic variables (such as financial development, macroeconomic stability, energy resources, trade openness, debt, imports, expenditures on R\&D, investment share in GDP, FDI, exchange rate, political stability, labour and labour productivity etc.) that may have significant impacts on the two main variables being studied. In spite of a clear conceptual link among HC, economic growth and exports, there exist a few empirical studies like Chuang (2000) for Taiwan and Narayan and Smyth (2004) for China that have examined the causal linkage among economic growth, HD and exports in a multivariate framework. There is hardly any study on Pakistan that examines the linkages among human capital, economic growth and exports. The present study is an attempt to examine both the SR and LR dynamic analysis of the relationship and causality among economic growth, HD and exports using Pakistan's data.

The main objectives of this study are:

- To empirically examine both the short-run and long-run dynamic relationships among economic growth, human development and exports in Pakistan.

- To examine the validity of human capital based endogenous growth theory, growth driven export and export-led growth hypotheses.

- To check the causal link among the variables being studied.

This study confines to Pakistan's economy on the dynamic relationships and causal nexus among economic growth, human development and exports. The HDI that is used as a composite measure of HD has been improving since 1970-71. The estimated HDI was 0.24 or 24 percent in 1970-71. This number increased to $0.34,0.44,0.51$ and 0.56 in 1980-81, 1990-91, 2000-01 and 2008-09, respectively. This means that the HD 
has improved more than double from 1970-71 to 2008-09 in Pakistan. The average annual increase in HDI remained at 2.25 percent from 1970-71 to 2008-09 that needs to be further improved in the coming years to cope with the requirement of latest technology used in Production. The growth of real exports in Pakistan has also been much rapid. It increased from Rs 74000 millions in 1970-71 to Rs 329086.1 millions and Rs 871956.9 millions in 1990-91 and 2007-08, respectively. The per annum average increase in real exports has been 6.89 percent from 1970-71 to 2007-08. The average annual export to GDP ratio has been below 10 percent from 1970-71 to 1989-90 in Pakistan. It fluctuated between 10 percent in 1990-91 to 13 percent in 2008-09. The average annual increase in Pakistan's real GDP has remained 5.25 percent from 1970-71 to 2008-09.

The remaining study is organised as under: Review of literature is presented in Section II. Section III includes specification of model, data sources and methodology. Empirical results are discussed in Section IV. Conclusion and recommendations have been given in Section V.

\section{REVIEW OF LITERATURE}

Many empirical studies exist in literature that have examined the linkage between exports and economic growth either by using correlation analysis or by using a bivariate causality analysis. Testing causality in a bivariate framework may not be very well free of specification bias. An important variable or variables may be missing or omitted in a bivariate causality case. Empirical studies on 'Export-led economic growth hypothesis' have supported mixed results in a bivariate causality framework. Empirical support for the validity of 'export-led growth hypothesis' in both developing and developed countries was found considerably weak in recent era when analysed by using cointigration and augmented Granger causality analysis rather than earlier correlation based or simple causality analysis. A few empirical studies also exist that have included other relevant variables (e.g. financial development, trade openness, debt, imports, expenditures on $\mathrm{R} \& \mathrm{D}$, share of investment in GDP, FDI, energy, exchange rate, labour stock and capital stock, etc.) for causality analysis and try to exert their influence on exports and economic growth. Afzal, Rehman, and Rehman (2008) tested the causality among economic growth, external debt servicing and exports in a bivariate and trivariate framework for Pakistan by applying Toda-Yamamoto Augmented Granger Causality analysis and found no support to 'export-led growth hypothesis'. Their study further supported the 'growthdriven export hypothesis'. The principal findings of the study by Shan and Sun (1998) do not support the validity of 'export-led growth hypothesis'. Awokuse (2003) tested the credibility of 'export-led growth hypothesis' for Canada and found it to be valid. Applying ARDL approach to cointegration and Toda-Yamamoto non-causality test, Omisakin (2009) found support for 'export-led growth hypothesis' for Nigeria. A comprehensive list of the studies that directly or indirectly have empirically examined the causality between economic growth and exports is given by Jung and Marshal (1985) for 37 developing countries and found one-way causality running from exports to growth for four countries only, Chow (1987) found causality running from exports to growth for only one country out of eight newly industrialised countries, Al-Yousif (1997) for Arab Gulf countries, Thornton $(1996,1997)$ for Mexico and Europe, Awokuse (2005) for Korea, Xu (1996) and Riezman, et al. (1996) for set of countries including Korea, Hong 
Kong and Taiwan, Bahmani-Oskooee, et al. (1991) for 20 countries, Kwan and Cotsomitis (1991) for China, Marin (1992) for industrialised countries, Shan and Sun (1998) for China, Hetemi and Manuchehr (2000) for Nordic economies, Ahmed and Kwan (1991) for 47 African countries and found no causality running from exports to growth, Lee and Pan (2000) for East Asian countries, Graves, et al. (1995) for Korea, Onchoke and In (1994) for selected South Pacific Island Nations, Mah (2005) for China, Hetemi (2003) for Japan, Demirhan, Erdal, and Akcay (2005) for selected MENA countries, Ahmad (2001), Kovacic and Djukic (1991) for Yugoslav economy, Jordaan and Eita (2007), Doganlar and Fisunoglu (1999) for Asian countries, Islam (1998), Baharumshah and Rashid (1999) for Malaysian economy, Khalid and Cheng (1997) for Singapore, Din (2004) for five largest economies of South Asia including Pakistan, Afzal (2006) for Pakistan, Ahmed, et al. (2000) for South and South-East Asian countries, Wernerheim (2000) for Canada, Reppas and Christopoulas (2005) for African and Asian countries, Amoateng and Adu (1996) for African Countries, Hsiao (1987) for newly Industrialised Asian economies, Ahmad and Harnhirun (1995) for Asian countries, Chuang (2000) for Taiwan, Narayan and Smyth (2004) for China, Liu, et al. (1997) for China, Shan and Tian (1998) for Shanghi (China), Konya (2006) for OECD countries, Shirazi and Manap (2004) for Pakistan and Afzal, Rehman, and Rehman (2008) for Pakistan.

Doganlar and Fisunoglu (1999) examined the causal linkage for seven Asian countries including Pakistan and found unidirectional causality running from economic growth to export growth in Pakistan. Vohra (2001) investigated linkage between export and economic growth for Pakistan, Philippines, Malaysia, Thailand and India, and found that exports positively affected the economic growth. Din (2004) explored the 'export-led growth hypothesis' for five South Asian countries including Pakistan and found cointegration among exports, imports, and output for Pakistan. Afzal (2006) found feedback causality between manufactured exports and GDP. Amoateng and Adu (1996) and Chen (2007) supported both the 'growth-driven exports' and 'Export-led economic growth hypotheses' in trivariate and tetravariate causality analysis respectively.

The linkages between (i) economic growth (EGr) and human capital (HC), (ii) HC and trade, and (iii) EGr and trade, have been studied and discussed by Narayan and Smyth (2004). A strong linkage was found between EGr and HD (Ranis, Stewart and Ramitez, 2000). Narayan and Smith (2004) tested Granger causality between HC and real income in a cointegrated VAR processes for China and found unidirectional Granger causality running from $\mathrm{HC}$ to real income in the LR while in SR, one-way Granger causality running from real income to HC. On one side, EGr supply the resources to improve HD and on the other side, HD in the form of improvements in quantity and quality of labour force contributes and accelerates EGr. Judson (2002) states that even though conventional wisdom does support a positive correlation between output growth and $\mathrm{HC}$, the empirical results are mixed, i.e., the positive correlation between growth and $\mathrm{HC}$ has been found exceptionally rather than as a rule. So, examining the causality between HD and EGr for Pakistan is the need of hour.

The contribution of EGr to HD is mainly through activities of households, government, NGOs and other civil society. The same level of income can contribute differently to HD. This depends upon the allocation of the income among households, 
government activities and on the behaviour and priorities of these sectors and institutions. Household disposable income directly contributes to the promotion of HD by making more expenditure on basic food, health and education. Poor households and female's control over cash income households are found to make more expenditures out of their income on HD related items than those with high income group and of male's control over cash income groups. Poor families and poor households are seen to spend less on education item of HD.

Birdsall (1985), Behrman and Wolfe (1987a, 1987b), King and Lillard (1987), Deolalikar (1993) and Alderman, Behrman Khan, Ross and Sabot (1996a, 1996b) have empirically proved for many countries including India and Pakistan that family earnings changes exerted a positive impact on child's schooling. On the other hand, improvements in HD depend upon government's expenditure on social sector and how much of the total public expenditure goes to HD related items especially on basic education and health. On the other hand, NGOs do contribute to HD by deriving resources from both domestic as well as foreign private and government donations. The effectiveness of NGOs varies from country to country. In some regions of the world, their role is just supplementary, but in other few countries (e.g. BRAC and Grameen Bank in Bangladesh, The Harambee School in Kenya and Peru's Comedores Populares), NGOs appeared as a major factor in the improvement and enhancement of HD (Riddell, Robinson, deConinck, Muir and White, 1995). Ghazali Education Trust (GET), Beaconhouse education system and Zindagi seem to improve and enhance HD in Pakistan.

High level of HD (in the form of improved health, nutrition and quality education) can contribute more to EGr. High level of HD affects the EGr by enhancing people's choices, capabilities, creativity and hence productivity. Better health and quality labour force education are the main determinants of exports and output growth. They also help in the proper and better utilisation of foreign borrowed technology very effectively. On one hand, quality secondary and tertiary education proved it to facilitate the acquisition of skills and managerial capabilities and on other hand, its contribution towards technological capability and technical change in industries is obvious and very important. The role of better health and quality education cannot be overlooked in the exports growth that affects the EGr. So there exists a positive significant correlation between EGr and exports. Ranis, Stewart and Ramirez (1997) explored the linkage between HD and EGr for the time period 1970-92. Their finding implied that, although both EGr and HD should be promoted jointly, but HD be given sequential priority.

According to Narayan and Smyth (2004), exports can promote HC accumulation in developing countries through three main channels. Firstly, exports, being the important component of trade help in facilitating transmission of technology to developing countries from developed countries. Transfer of technology is biased in favour of skilled labour and induces investment in HC [Pissarides (1997)]. Secondly, export is a source of learning by doing. Thirdly, the diffusion of soft and hard technologies including marketing, production and management expertise can be promoted by exports which in turn accelerate the productivity of factors of production such as labour and capital [Grossman and Helpman (1991); Kim (1998)]. Improvements in HC can Granger cause exports. Improvements in $\mathrm{HC}$ stock can increase the quality of workforce that, in turn, raises the labour productivity and accelerates further exports and hence EGr [Chuang 
(2000)]. Gould and Ruffin (1995), Hanson and Harison (1995) and Stokey (1996) conducted studies for different countries and for different time periods and suggested that $\mathrm{HC}$ accumulation was accelerated and promoted by trade and vice versa.

Expansion in exports can increase growth through a variety of channels. 'Exportled growth hypothesis' is one of them. 'Export-led growth hypothesis' postulates that exports expansion is vital to EGr. It raises investment and employment opportunities, production efficiency, technological advancement, and hence EGr. On the other way, EGr can also increase exports [see Ahmed (2001); Afzal, Rehman, and Rehman (2008)]. Jung and Marshall (1985) found that the internally generated economic growth better explained exports growth. New trade theories also support growth causing exports hypothesis [e.g. see Helpman and Krugman (1990)]. It is concluded from the above discussion that high exports economies also perform well in their growth rate of GDP. Such type of linkages between EGr and exports induce the researchers to examine the causality between the two.

Empirical analysis based on bivariate causality framework on both the hypotheses has provided the diverse results. However, a few studies have been found in literature that tested causality between the HD and EGr. The studies that tested the bivariate causality between HD and EGr include De Meulemuster and Rochat (1995) for six developed countries including Sweden, UK, Japan, France, Italy and Australia, In and Doucouliagos (1997) for US, and Asteriou and Agiomirgianakis (2001) for Greece. All the studies conducted for developed countries provide mix results about unidirectional and bidirectional causality. Lee and Lee (1995) utilised secondary school achievement test score as a direct measures of $\mathrm{HC}$ for 17 developed and developing countries including India, Iran and found that the higher initial HC stock per worker led to higher economic growth per worker. A few studies have been carried out for the developing countries. A study conducted for Pakistan by Khan, et al. (1991) found one-way Granger causality running from literacy to productivity for Pakistan. Narayan and Smyth (2004) tested temporal bivariate causality between real income and $\mathrm{HC}$ in a co-integrated VAR processed for China for the time period 1960 to 1999 and found the evidence of log run Granger causality running from $\mathrm{HC}$ to real income while the short run one way causality running from real income to $\mathrm{HC}$ was observed.

A few studies also exist in literature that has tested the causal link between exports and EGr by including HD as a third variable in a multivariate framework. Chuang (2000) tested the casual linkages among exports, HC and EGr for Taiwan for the period 1952-95. $\mathrm{He}$ found the bidirectional casualty between exports and $\mathrm{HC}$ accumulation. $\mathrm{HC}$ based endogenous growth theory and export-led growth hypothesis were found valid in case of Taiwan. Narayan and Smyth (2004) employed co-integration and error correction techniques to test the casualty among real income, real exports and HC stock for China using annual data over the period 1960 to 1999 and found evidence of co-integration among real income, real exports and $\mathrm{HC}$ when real exports served as dependent variable and $\mathrm{HC}$ and real income are taken as independent variables. They found (i) the evidence of short run bi-directional Granger causality between $\mathrm{HC}$ and real exports, (ii) unidirectional Granger causality running from real income to $\mathrm{HC}$ and (iii) no evidence of Granger causality between real exports and real income. Furthermore their results do not support the 'export-led growth hypothesis'. 
In the present study, the validity of 'growth-driven exports' and 'export-led growth hypotheses' are examined in case of Pakistan by including HD as a third variable. In addition, the validity of human-based endogenous growth theory is also tested for Pakistan.

\section{MODEL SPECIFICATION, METHODOLOGY AND DATA SOURCES}

This study employs annual time series of real gross domestic product $(R G D P)$, real exports $(R X)$, physical capital $(P C)$ and human development $(H D)$ in Pakistan for the period 1970-71 to 2008-09, drawn from various issues of Pakistan Economic Survey and Annual Reports of State Bank of Pakistan. A time series for HDI for the period 1970-71 to 2008-09 has been constructed by using UNDP methodology developed in 1999-2000. The variables GDP and exports have been converted into real terms by GDP deflator and export prices, respectively. Where as physical capital $(P C)$ has been measured by the real fixed capital formation.

Keeping in view the theoretical postulates of the relationship among $R G D P, P C$, $R X$ and $H D$ the following models have been specified as:

$\begin{array}{lllllll}\ln R G D P=f(\ln P C, \ln R X, \ln H D) & \ldots & \ldots & \ldots & \ldots & \ldots & (1) \\ \ln R X=f(\ln P C, \ln R G D P, \ln H D) & \ldots & \ldots & \ldots & \ldots & \ldots & (2) \\ \ln H D=f(\ln P C, \ln R G D P, \ln R X) & \ldots & \ldots & \ldots & \ldots & \ldots & (3)\end{array}$

Where ln stands for natural logarithm, and

$$
\begin{aligned}
R G D P= & \text { Real GDP; a measure of economic growth: current GDP at market prices } \\
& \text { is deflated by GDP deflator. } \\
P C= & \text { Since time series data on capital stock is not directly available for } \\
& \text { Pakistan. Physical capital is proxied by real value of gross fixed capital } \\
& \text { formation. GFCF deflated by GDP deflator; a proxy used to measure real } \\
& \text { physical capital. "Fixed capital formation measures both private and } \\
& \text { public national investment" [Balasubramanyam, Salisu and Sapsford } \\
& \text { (1996); Hansen and Rand (2006)]. This proxy for real PC has been used } \\
& \text { by Kohpaiboon (2004) and Mansouri (2005). } \\
R X= & \text { Real exports; an important component of trade and is considered as } \\
& \text { important ingredient of progress and prosperity of a nation. Here exports } \\
& \text { are converted into real exports by using unit value indexes of exports. } \\
H D= & \text { HDI; a composite measure of human development. }
\end{aligned}
$$

The Model 1 is a kind of production function augmented by $R X$ and $H D$. The relationship among variables under consideration is expected to be positive.

In literature human capital development was measured by using different proxy variables like labour force employment, average years of schooling, educational attainments, the number of employed workforce with tertiary education, public expenditures on education and health, R\&D expenditures, secondary school achievement test scores and literary rates etc., however, these proxy variables cannot fully capture the notion of HD and has been questioned and criticised [e.g. see Judson (2002)]. In order to 
capture the effect of HD on EGr, a direct and more reliable measure of HD is needed. In this study, a composite measure of HD known as HDI is constructed by using UNDP latest methodology for the period 1970-71 to 2008-09.

Several methods such as residual based Engle-Granger (1987) test, Johansen (1988), Johansen-Juselius (1990), Gregory and Hansen (1996), Saikkonen and Lutkepohl (2000), and ARDL approach to cointegration are available in literature. Since this study aims at detecting SR and LR linkages between EGr, HD and exports, it uses a relatively new estimation technique known as Bounds Testing Approach to Cointegration within ARDL framework. A brief description of ARDL approach is given below:

\section{Autoregressive Distributive Lag (Ardl) Approach to Cointegration}

The Proposed ARDL approach to cointegration is developed by Pesaran and Pesaran (1997), Pesaran and Shin (1995 and 1998) and further advanced by Pesaran, et al. (2001). It is a unification of autoregressive models and distributed lag models. In an ARDL model, a time series is a function of its lagged values and current and lagged values of one or more explanatory variables. There are several benefits for the use of ARDL approach to cointegration. Bivariate cointegration test and multivariate cointegration techniques given by Stock and Watson (1988), Johansen $(1988,1991)$ and Johansen and Juselius (1990) perform better for large samples. However, ARDL technique to cointegration is more appropriate for small samples (30 to 80 values). ARDL technique to cointegration not only can distinguish dependent and explanatory variables (i.e. it avoids the problem of endogeneity) but also ARDL method can simultaneously estimate the LR and SR components of the model. This technique also removes the problems related to omitted variables and autocorrelation. The parameter estimates obtained from the ARDL approach are unbiased and efficient because they avoid the problems that may arise due to serial correlation and endogeneity [Pesaran, Shin, and Smith (2001)].

A dynamic error correction model (ECM) through linear transformation can be derived from ARDL [Banerjee, et al. (1993)] that permits to draw inference for LR estimates that is not available in other alternative cointegation procedures [Sezgin and Yildirim (2002)].

ARDL approach to cointegration has some superiority over Engle and Granger (1987) single equation cointegration technique. The ARDL method to cointegration can be applied irrespective of whether the regressors are of $\mathrm{I}(0), \mathrm{I}(1)$ or mutually integrated but it is still prerequisite that the dependent variable is of $\mathrm{I}(1)$ in levels and none of the explanatory variables is $\mathrm{I}(2)$ or higher order. In ARDL procedures to cointegration, different variables may have diverse optimal number of lags, which in other standard cointegration techniques like Johansen type approaches, is not possible. Apart from the superiority of ARDL model over other cointegration techniques, this study preferred to apply ARDL approaches to cointegartion because of the following two main reasons:

(i) Bounds test procedure's results are robust in case of small or finite samples (i.e. 30 to 80 observations as is the case in this study).

(ii) Real income and real exports variables are of I(1), while HDI is $\mathrm{I}(0)$ or fractionally integrated. 
All these justify the application of ARDL model to determine the relationship among EGr, HD and exports in Pakistan.

\section{Bounds Testing Approach to Cointegration}

The 2nd stage procedure of this paper involves the testing of the existence of short-run (SR) and long-run (LR) relationship between real gross domestic product (RGDP), real exports (RX), physical capital (PC) and human capital (HD) within a multivariate framework. To examine the existence of SR and LR relationship the errorcorrection version of ARDL model of Equations 1, 2, and 3 by following Pesaran and Pesaran (1997: 397-9) and Pesaran and Shin (1999), can be used as:

$$
\begin{aligned}
& \Delta \ln (\mathrm{Y})=a_{0 \mathrm{Y}}+\sum_{i=1}^{n} b_{i Y} \Delta \ln (\mathrm{Y})_{t-i}+\sum_{i=0}^{n} c_{i Y} \Delta \ln (\mathrm{PC})_{t-i}+\sum_{i=0}^{n} d_{i Y} \Delta \ln (\mathrm{RX})_{t-i} \\
& +\sum_{i=0}^{n} e_{i Y} \Delta \ln (\mathrm{HD})_{t-i}+\delta_{1 \mathrm{Y}} \ln \mathrm{Y}_{t-1}+\delta_{2 \mathrm{Y}} \ln \mathrm{PC}_{t-1}+\delta_{3 \mathrm{Y}} \ln \mathrm{RX}_{t-1} \\
& \Delta \ln (\mathrm{RX})=a_{0 \mathrm{RX}}+\sum_{i=1}^{n} b_{i R X} \Delta \ln (\mathrm{RX})_{t-i}+\sum_{i=1}^{n} c_{i R X} \Delta \ln (\mathrm{PC})_{t-i}+ \\
& \sum_{i=0}^{n} d_{i R X} \Delta \ln (\mathrm{Y})_{t-i}+\sum_{i=0}^{n} e_{i R X} \Delta \ln (\mathrm{HD})_{t-i}+\delta_{1 \mathrm{RX}} \ln \mathrm{RX}_{t-1}+ \\
& \delta_{2 \mathrm{RX}} \ln \mathrm{PC}_{t-1}+\delta_{3 \mathrm{RX}} \ln \mathrm{Y}_{t-1}+\delta_{4 \mathrm{RX}} \ln \mathrm{HD}_{t-1} \quad \ldots \quad \ldots \quad \ldots \quad \ldots \quad \text { (丂) } \\
& \Delta \ln (\mathrm{HD})=a_{0 \mathrm{HD}}+\sum_{i=1}^{n} b_{i H D} \Delta \ln (\mathrm{HD})_{t-i}+\sum_{i=1}^{n} c_{i H D} \Delta \ln (\mathrm{PC})_{t-i}+ \\
& \sum_{i=0}^{n} d_{i H D} \Delta \ln (\mathrm{Y})_{t-i}+\sum_{i=0}^{n} e_{i H D} \Delta \ln (\mathrm{RX})_{t-i}+\delta_{1 \mathrm{HD}} \ln \mathrm{HD}_{t-1}+ \\
& \delta_{2 \mathrm{HD}} \ln \mathrm{PC}_{t-1}+\delta_{3 \mathrm{HD}} \ln \mathrm{Y}_{t-1}+\delta_{4 \mathrm{HD}} \ln \mathrm{RX}_{t-1}
\end{aligned}
$$

The coefficients $(a, b, c, d, e)$ of part first of Equations ( 4,5 and 6$)$ measure the SR dynamics of the model whereas $\delta$ s represent the LR relationships.

ARDL model uses a three-step procedure:

(a) Dynamic analysis.

(b) Long-run relationship.

(c) ECM analysis.

The 1st step in the ARDL approach to cointegration is to examine LR relationship among the variables by carrying out familiar F-test on the differenced variables components of Unrestricted Error Correction Mechanism (UECM) model for the joint significance of the coefficients of lagged level of the variables. In this first step, the regression equation estimated for the dependent variable RGDP $(Y)$ is defined as 


$$
\begin{aligned}
& \Delta \ln (\mathrm{Y})=a_{0 \mathrm{Y}}+\sum_{i=1}^{n} b_{i Y} \Delta \ln (\mathrm{Y})_{t-i}+\sum_{i=1}^{n} c_{i Y} \Delta \ln (\mathrm{PC})_{t-i}+\sum_{i=0}^{n} d_{i Y} \Delta \ln (\mathrm{RX})_{t-i}
\end{aligned}
$$

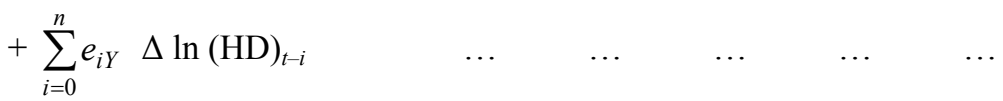

To create error correction mechanism in this step, the first lag of the level of each variable is added to the Equation (7) and a variable Addition Test is conducted by calculating F-test on the joint significance of all the added lagged level variables.

$$
\begin{aligned}
& \Delta \ln (\mathrm{Y})=a_{0 \mathrm{Y}}+\sum_{i=1}^{n} b_{i Y} \Delta \ln (\mathrm{Y})_{t-i}+\sum_{i=0}^{n} c_{i Y} \Delta \ln (\mathrm{PC})_{t-i}+\sum_{i=0}^{n} d_{i Y} \Delta \ln (\mathrm{RX})_{t-i} \\
& +\sum_{i=0}^{n} e_{i Y} \Delta \ln (\mathrm{HD})_{t-i}+\delta_{1 \mathrm{Y}} \ln \mathrm{Y}_{t-1}+\delta_{2 \mathrm{Y}} \ln \mathrm{PC}_{t-1}+\delta_{3 \mathrm{Y}} \ln \mathrm{RX}_{t-1} \\
& +\delta_{4 \mathrm{Y}} \ln \left(\mathrm{HD}_{t-1}\right)
\end{aligned}
$$

The null hypothesis of no cointegration for RGDP against alternative hypothesis is tested by taking into account the UECM model as:

$\mathrm{H}_{0}: \quad \delta_{1 Y}=\delta_{2 Y}=\delta_{3 Y}=\delta_{4 Y}=0$

$\mathrm{H}_{1}$ : None of the coefficients $\left(\delta_{1 Y}, \delta_{2 Y}, \delta_{3 Y}, \delta_{4 Y}\right)=0$

This is denoted as $F_{Y}(Y \mid P C, R X$, and $H D)$.

In Equation (2) where exports is the regress and, the null hypothesis of no cointegration for exports against alternative hypothesis of cointegration is as under:

$\mathrm{H}_{0}: \quad \delta_{1 R X}=\delta_{2 R X}=\delta_{3 R X}=\delta_{4 R X}=0$

$\mathrm{H}_{1}$ : None of the coefficients $\left(\delta_{1 R X}, \delta_{2 R X}, \delta_{3 R X}, \delta_{4 R X}\right)=0$

and is denoted as $F_{R X}(R X \mid Y, P C, H D)$

In Equation (3), where $\mathrm{HC}$ is the dependent variable, the null hypothesis of no cointegration against alternative hypothesis of cointegration is as under:

$\mathrm{H}_{0}: \quad \delta_{1 H D}=\delta_{2 H D}=\delta_{3 H D}=\delta_{4 H D}=0$

$\mathrm{H}_{1}$ : None of the coefficients $\left(\delta_{1 H D}, \delta_{2 H D}, \delta_{3 H D}, \delta_{4 H D}\right)=0$

and is denoted as $F_{H D}(H D \mid Y, P C, R X)$

The above hypotheses can be tested by applying standard F-statistic. However, the asymptotic distribution of this F-statistic is non-standard irrespective of whether the variables included in the model are $\mathrm{I}(0)$ or $\mathrm{I}(1)$. The value of $\mathrm{F}$ depends upon (i) number of explanatory variables, (ii) intercept and/or a trend of ARDL, and (iii) sample size. Pesaran, et al. (2001) have "tabulated two sets of appropriate critical values. One set assumes all variables are $\mathrm{I}(1)$ and another assumes that they are all $\mathrm{I}(0)$. This provides a band covering all possible classifications of the variables into $\mathrm{I}(1)$ or $\mathrm{I}(0)$ or even fractionally integrated." Critical values of Pesaran, et al. (2001) are valid for large sample while Narayan (2005) and Tuener (2006) have provided two sets of critical values for small sample size (30 to 80 observations).

The value of F-statistic found from the data is then compared to the non-standard two sets of critical bound values developed by Pesaran, et al. (2001). This comparison is 
made as follows. If the calculated value of F-statistic lies outside the critical bounds then a conclusive decision about cointegration can be made having no knowledge of order of integration of the regressors. If the calculated value of F-statistic is bigger than the asymptotically upper bound value, cointegration will establish. On the other hand, cointegration is not established if the calculated value of F-statistic is smaller than the critical lower bound value. The F-test becomes inconclusive about cointegration if the value of F-statistic lies between the critical lower and upper bounds values. In such cases, the order of integration of the variables under consideration is checked by following the procedure developed by Johansen and Juselius (1990) for detection of cointegration. When the order of integration of the variables under consideration is known already and the variables are of I(1) upper bounds are used to make the decision. The decision of optimum lag length can be made by using either Akaike Information Criteria or Schwartz-Bayesian criteria or R-bar criteria or Human-Quinn criteria. In case of inclusive situation, use of ECM version of ARDL model is regarded as the efficient way of establishing cointegration by Kremers, et al. (1992) and Bannerjee, et al. (1998). Cointegration is established if the ECM coefficient is negative and highly significant.

Stability of the model is checked as the second step in ARDL bounds testing procedure. After establishing cointegration, the model based on Equation (4) to Equation (6) is estimated by using an appropriate lag criterion such as Akaike Information Criterion or Schwarz Bayesian criteria. Completion of second stage gives estimates of LR elasticities as well as enables the use of CUSUM and CUSUM Sum of Squares tests to the residuals of Equation (4) to Equation (6) for testing the stability of LR elasticities along with SR dynamics.

To establish the stability of SR estimated coefficients of the first differenced variables as well as LR parameters, CUSUM and CUSUM Sum of Squares tests proposed by Brown, et al. (1975) were employed by Pesaran and Pesaran (1977). The statistics of CUSUM and CUSUM Sum of Squares are updated recursively and are plotted against the break points after breaking the sample period. The coefficient estimates are called stable if the plot of CUSUM and CUSUM Sum of Squares stay within 5 percent significance level (portrayed by two straight lines based on equations developed by Brown, et al. (1975).

Though the existence of LR relationship among the variables is of very interest, it may be even more relevant to examine the SR dynamics. So the next step of the analysis is the formulation of ECM, as has been done previously in the 2nd stage procedure of the paper. $E C M$ best describes the SR dynamics consistently with the LRrelationship. The coefficient of ECM(-1) term known as adjustment parameter indicates speed of adjustment and the negative sign and its highly statistical significant confirms cointegration and determines the LRcausal effect. The negative sign of the adjustment parameter also ensures stability of the model. The negative and statistical significant sign of the coefficient of $E C M_{t-1}$ also implies that the series are non-explosive and LR equilibrium is attained.

\section{EMPIRICAL RESULTS AND ANALYSIS}

\section{Unit Root Tests}

Using the ARDL technique avoids the classification of variables into $I(1)$ or $I(0)$ or mutually integrated and there is no need for unit root pre-testing unlike other 
standard cointegration tests [Pesaran, et al. (2001)]. Sezgin and Yildirim (2002) and Ouattara (2004) reported that the calculated F-statistic provided by Pesaran, et al. (2001) becomes invalid in the existence of $I(2)$ variables. Therefore, testing the unit root in the ARDL procedures is necessary to avoid the possibility of spurious regression and to ensure that not a single variable is of $I(2)$ or above. For this purpose, the order of integration of the variables under study was tested using Augmented Dickey-Fuller (ADF), Phillip-Perron (PP), Dickey-Fuller Generalised Least Square (DF-GLS) and Ng-Perron tests. Phillip-Perron test has the extra merit over the ADF test, i.e. it has been adjusted to capture serial correlation. This study also employed the Ng-Perron (2001) modified unit root test because it is considered more suitable for small samples than the traditional tests. Applying the Ng-Perron unit root test, the null hypothesis of unit root is not over rejected [Ng-Perron (2001); Sinha Dipendra (2007); Omisakin (2008)]. Different unit root tests results for the variables under consideration are reported in Tables 1,2 and 3. The results reveal that the log of real GDP, PC and RX series are not stationary in their level but are stationary at their first difference at 1 percent level of significance in PP, DF-GLS and ADF unit roots tests, while log of real GDP is stationary at its first difference at 10 percent level of significance according to Ng-Perron test. Table 1 also indicates that $\log$ of HDI series is stationary at its level form at 2 percent and 1 percent level of significance according to ADF and PP unit root tests but Tables 2 and 3 reveal that HDI is stationary at its first difference with constant and intercept according to both DF-GLS and Ng-Perron unit root criteria. Therefore, it is concluded that log of real GDP, PC, RX are integrated of order 1, i.e. I(1), while log of HDI series is integrated of order 0 with constant, i.e. I(0) in both ADF and PP unit roots tests. HDI series is of I(1) at both Ng-Perron and DF-GLS criteria. All the unit root tests ensure that none of the variables is $\mathrm{I}(2)$ or higher order.

Table 1

Unit Root Analysis: $A D F$ and PP

\begin{tabular}{|c|c|c|c|c|}
\hline \multirow[b]{2}{*}{ Variables } & \multicolumn{2}{|c|}{ Augmented Dickey-Fuller Test (ADF) } & \multicolumn{2}{|c|}{ Phillips-Perron Test (PP) } \\
\hline & Intercept & Intercept and Trend & Intercept & Intercept and Trend \\
\hline $\ln \mathrm{Y}$ & $-2.4430(0.1373)$ & $-1.3875(0.8486)$ & $-2.2227(0.2019)$ & $-1.4682(0.8230)$ \\
\hline$\Delta \ln \mathrm{Y}$ & $-4.8816(0.0003)$ & & $-4.8786(0.0003)$ & \\
\hline $\ln \mathrm{PC}$ & $-0.8267(0.7999)$ & $-2.2951(0.4263)$ & $-1.1908(0.6685)$ & $-2.0294(0.5670)$ \\
\hline$\Delta \ln \mathrm{PC}$ & $-4.8394(0.0004)$ & & $-5.4943(0.0001)$ & \\
\hline $\ln \mathrm{RX}$ & $-0.8830(0.7828)$ & $-2.7279(0.2318)$ & $-0.8756(0.7851)$ & $-2.7882(0.2101)$ \\
\hline$\Delta \ln \mathrm{RX}$ & $-6.4063(0.0000)$ & & $-6.4077(0.0000)$ & \\
\hline $\ln \mathrm{HD}$ & $-3.3506(0.0198)$ & & $-4.3180(0.0015)$ & \\
\hline
\end{tabular}

Values in parentheses are p-values. 
Table 2

Unit Root Analysis: DF-GLS

\begin{tabular}{lcc}
\hline & Dickey-Fuller Generalised Least Square Test Statistic (DF-GLS) \\
\cline { 2 - 3 } Variables & Intercept & Intercept and Trend \\
\hline $\ln \mathrm{Y}$ & 0.8684 & -0.9883 \\
$\Delta \ln \mathrm{Y}$ & $-2.8392^{*}$ & \\
$\ln \mathrm{PC}$ & 1.0012 & -2.2889 \\
$\Delta \ln \mathrm{PC}$ & $-4.4047^{*}$ & \\
$\ln \mathrm{RX}$ & 0.3168 & -2.88330 \\
$\Delta \ln \mathrm{RX}$ & $-4.4432^{*}$ & -2.3291 \\
$\ln \mathrm{HD}$ & 0.1771 & $-8.4393^{*}$ \\
$\Delta \ln \mathrm{HD}$ & -0.4329 & \\
\hline
\end{tabular}

$*, * *, * * *$ Indicate 1 percent, 5 percent and 10 percent level of significance.

Table 3

Unit Root Analysis: Ng-Perron

\begin{tabular}{|c|c|c|c|c|}
\hline Variables & Mza & $\mathrm{MZt}$ & MSB & MPT \\
\hline $\ln \mathrm{Y}$ with constant & 0.8892 & 0.6426 & 0.7227 & 38.7505 \\
\hline ln $\mathrm{Y}$ with constant and trend & -2.8280 & -1.0754 & 0.3802 & 28.9286 \\
\hline$\Delta \ln \mathrm{Y}$ with constant & -7.6100 & -1.8656 & 0.2451 & 3.5259 \\
\hline In PC with constant & 1.5305 & 1.7467 & 1.1412 & 97.8290 \\
\hline In PC with constant and trend & -8.0820 & -2.0026 & 0.2478 & 11.2968 \\
\hline$\Delta \ln \mathrm{PC}$ with constant & -17.99927 & -2.9481 & 0.1638 & 1.5470 \\
\hline ln RX with constant & 0.8025 & 0.7912 & 0.9860 & 65.0975 \\
\hline ln RX with constant and trend & -11.9087 & -2.3020 & 0.1933 & 8.3644 \\
\hline$\Delta \ln \mathrm{RX}$ with constant & -15.3935 & -2.7060 & 0.1713 & 1.9340 \\
\hline ln HD with constant & 0.9562 & 0.9936 & 1.0391 & 73.8157 \\
\hline ln HD with constant and trend & -6.4746 & -1.6499 & 0.2549 & 14.0830 \\
\hline$\Delta \ln$ HD with constant & -1.0385 & -0.6010 & 0.5789 & 18.4891 \\
\hline$\Delta \ln \mathrm{HD}$ with constant and trend & -15.0962 & -2.7472 & 0.1820 & 6.0374 \\
\hline $1 \%$ Level of Significance (with constant) & -13.8000 & -2.5800 & 0.1740 & 1.7800 \\
\hline $5 \%$ Level of Significance (with constant) & -8.1000 & -1.9800 & 0.2330 & 3.1700 \\
\hline $10 \%$ Level of Significance (with constant) & -5.7000 & -1.6200 & 0.2750 & 4.4500 \\
\hline $1 \%$ Level of Significance (with constant and trend) & -23.8 & -3.42 & 0.143 & 4.03 \\
\hline $5 \%$ Level of Significance (with constant and trend) & -17.3 & -2.9 & 0.168 & 5.48 \\
\hline $10 \%$ Level of Significance (with constant and trend) & -14.20 & -2.62 & 0.185 & 6.67 \\
\hline
\end{tabular}

Since the results presented in Tables 1, 2 and 3 indicate that all the variables expect HD are of I(1). According to ADF and PP tests, HD is integrated of order 0 , while according to DF-GLS and Ng-Perron Unit Roots HD is integrated of order 1. None of the variables is of $\mathrm{I}(2)$. So this study applied the ARDL procedure with such mixed integrated result (i.e. of $\mathrm{I}(1)$ or $\mathrm{I}(0)$ or fractionally integrated).

Bahmani-Oskooee and Nasir (2004) have argued that the first step in any cointegration technique is "to determine the degree of integration of each variable in the model", but different unit root tests yield different results. For example, while applying the traditional ADF and PP tests one may mistakenly conclude that a unit root is present in a series that is actually stationary around a 1-time structural break [for further details, please consult Perron (1989); Perron (1997)]. This study uses ARDL procedures to avoid this unit root related problem. 


\section{Cointegration}

Following the first step in the ARDL approach to cointegration, this study examines LR relationship between the variables by conducting partial F-test. This test is sensitive to the number of lags used on each first differenced variable [Bahmani-Oskooee and Brooks (1999)]. In this study lags up to four periods have been imposed on each first differenced variable. The estimated F-statistic for RGDP, RX and HD of Models 1, 2 and 3 are reported in Table 4.

Table 4

Bounds Testing Approach to Cointegration: Results of F-Test for Cointegration

\begin{tabular}{|c|c|c|c|c|c|}
\hline & \multicolumn{4}{|c|}{ Lag Length } & \multirow[b]{2}{*}{ Outcome } \\
\hline & 1 & 2 & 3 & 4 & \\
\hline$\Delta \mathrm{Y}\left\{\mathrm{F}_{\mathrm{Y}}(\mathrm{Y} \mid \mathrm{PC}, \mathrm{RX}, \mathrm{HD})\right\}$ & 0.53 & 0.45 & 0.70 & 0.60 & No Cointegration \\
\hline$\Delta \mathrm{RX}\left\{\mathrm{F}_{\mathrm{RX}}(\mathrm{RX} \mid \mathrm{PC}, \mathrm{Y}, \mathrm{HD})\right\}$ & 2.27 & 3.17 & 1.56 & 2.94 & No Cointegration \\
\hline$\Delta \mathrm{HD}\left\{\mathrm{F}_{\mathrm{HD}}(\mathrm{HD} \mid \mathrm{PC}, \mathrm{Y}, \mathrm{RX})\right\}$ & 4.48 & 10.17 & 6.37 & 12.35 & Cointegration \\
\hline
\end{tabular}

Lower and upper Critical values for bounds testing ARDL for 1 percent, 5 percent and 10 percent significance levels are 3.65-4.66, 2.79-3.67and 2.37-3.20 respectively.

It is at least one F-value that is higher than the upper critical value, supporting cointegration among RGDP, RX, PC and HD when HD is the dependent variable. The null hypothesis of no cointegration is not rejected when real GDP and RX are serving as dependent variables in Models 1 and 2 respectively because at least one F-value is not higher than the upper critical bounds value. However, the results at this stage are considered preliminary and this study seeks for more evidence of cointegration in the second stage of the analysis when an appropriate lag selection criterion is employed. Once cointegration among the variables of interest is established, then models 1,2 , and 3 were estimated by using ARDL approach.

By using ARDL approach, Equation (4) was estimated with and without HD variable in addition to $\mathrm{PC}$ and RX. The estimated results are presented in Table 5. The results of estimated dynamic ARDL models presented in Table 5 clearly support the fact that the RX is not significant in explaining the real GDP in Pakistan. This also seems to refute the 'export-led growth hypothesis' in Pakistan.

The stability of the LR coefficients together with SR dynamics was tested by plot of cumulative sum of recursive residuals (CUSUM) and by plot of cumulative sum of squares of recursive residuals (CUSUM SQUARE) tests. The results of CUSUM and CUSUM SQUARE tests proposed by Brown, Durbin and Evans (1975) reside within a 5 percent level of significance (portrayed by two straight lines). This reveals the significant and stable relation among the variables. This also indicates that there is no evidence of any significant structural instability (Figures 1 and 2). 
Table 5

Dynamic ARDL Model Based on Schwarz Bayesian Criterion (SBC) (Dependent Variable $=$ ln Real GDP $(Y))$

\begin{tabular}{|c|c|c|c|c|}
\hline \multirow[b]{2}{*}{ Regressor } & \multicolumn{2}{|c|}{ ARDL $(1,0,1)$ without HD } & \multicolumn{2}{|c|}{ ARDL $(1,2,0,1)$ with HD } \\
\hline & Coefficient & $\overline{\text { t-ratio (P-value) }}$ & Coefficient & t-ratio (P-value) \\
\hline $\ln \mathrm{Y}(-1)$ & 0.94303 & $24.55531(0.000)$ & 0.77323 & $10.6354(0.000)$ \\
\hline $\ln \mathrm{PC}$ & 0.061905 & $2.5331(0.017)$ & 0.10164 & $2.7938(0.009)$ \\
\hline $\ln \mathrm{PC}(-1)$ & & & -0.093395 & $-2.1006(0.045)$ \\
\hline $\ln \mathrm{PC}(-2)$ & & & 0.086539 & $2.5535(0.016)$ \\
\hline $\ln \mathrm{RX}$ & 0.041970 & $1.5403(0.134)$ & 0.021026 & $0.82891(0.414)$ \\
\hline $\ln \mathrm{RX}(-1)$ & -0.06058 & $-2.3030(0.028)$ & & \\
\hline $\ln \mathrm{HD}$ & & & 0.082867 & $0.22360(0.825)$ \\
\hline $\ln \mathrm{HD}(-1)$ & & & 0.17102 & $2.1854(0.037)$ \\
\hline \multirow[t]{2}{*}{ Constant } & 0.32259 & $1.5260(0.137)$ & 2.0780 & $2.6518(0.013)$ \\
\hline & \multicolumn{2}{|c|}{$\begin{array}{l}\bar{R}^{2}=0.99900, \text { F-stat }=8734.1(0.000), \mathrm{SBC} \\
=90.36, \text { Serial Correlation }(\mathrm{LM})=0.0015 \\
(0.969), \text { Ramsey's Reset Test }=0.8314 \\
(0.362), \text { Heteroscedasticity }(\mathrm{LM})=0.3986 \\
(0.528), \text { Normality }(\mathrm{LM})=0.4875(0.784)\end{array}$} & \multicolumn{2}{|c|}{$\begin{array}{l}\bar{R}^{2}=0.99915, \text { F-stat }=5853.6(0.000), \\
\text { SBC }=89.69, \text { Serial Correlation }(\mathrm{LM})= \\
0.0435(0.801), \text { Ramsey's Reset Test }= \\
1.6939(0.1963), \text { Heteroscedasticity }(\mathrm{LM})= \\
0.02886(0.591), \text { Normality }(\mathrm{LM})=0.9489 \\
(0.622)\end{array}$} \\
\hline
\end{tabular}

The figures in parentheses are P-values.

Fig. 1(a). Plot of Cumulative Sum of Recursive Residuals

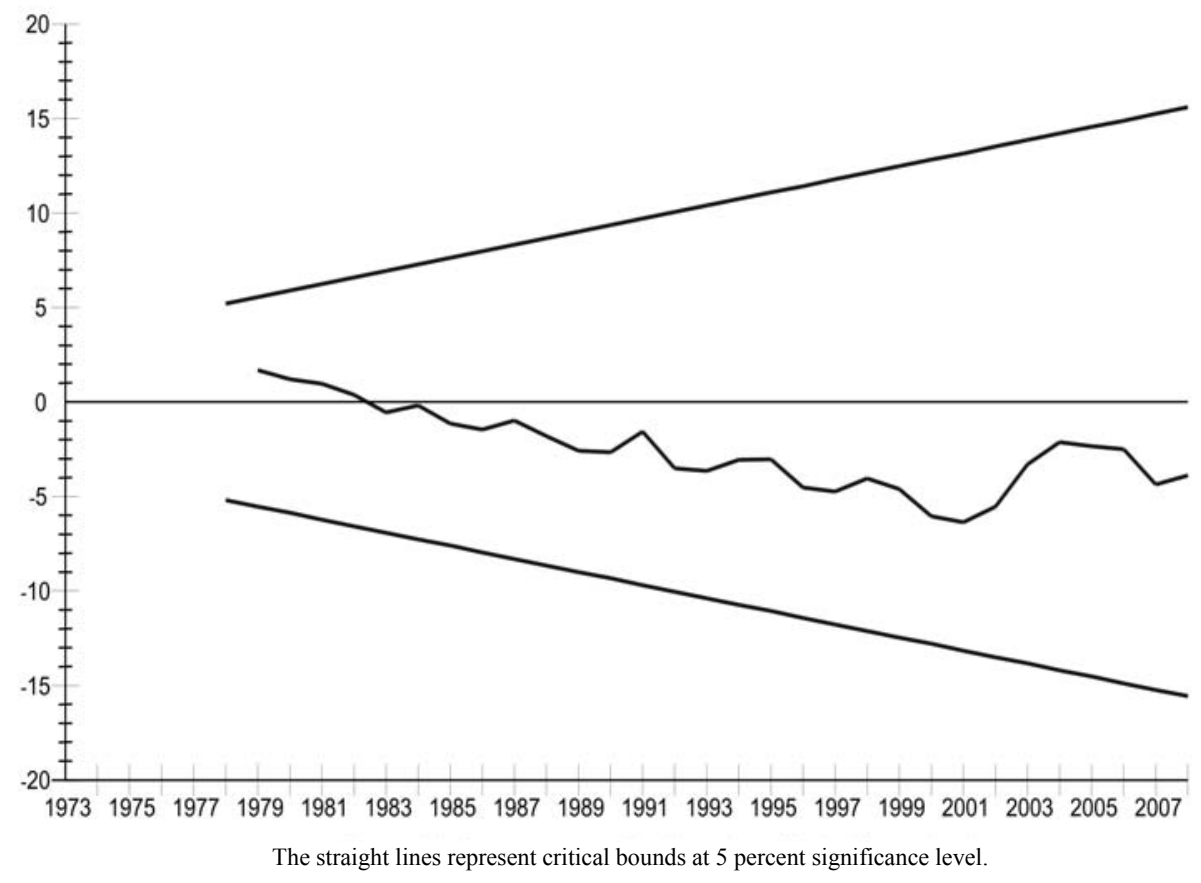


Fig. 1(b). Plot of Cumulative Sum of Squares of Recursive Residuals

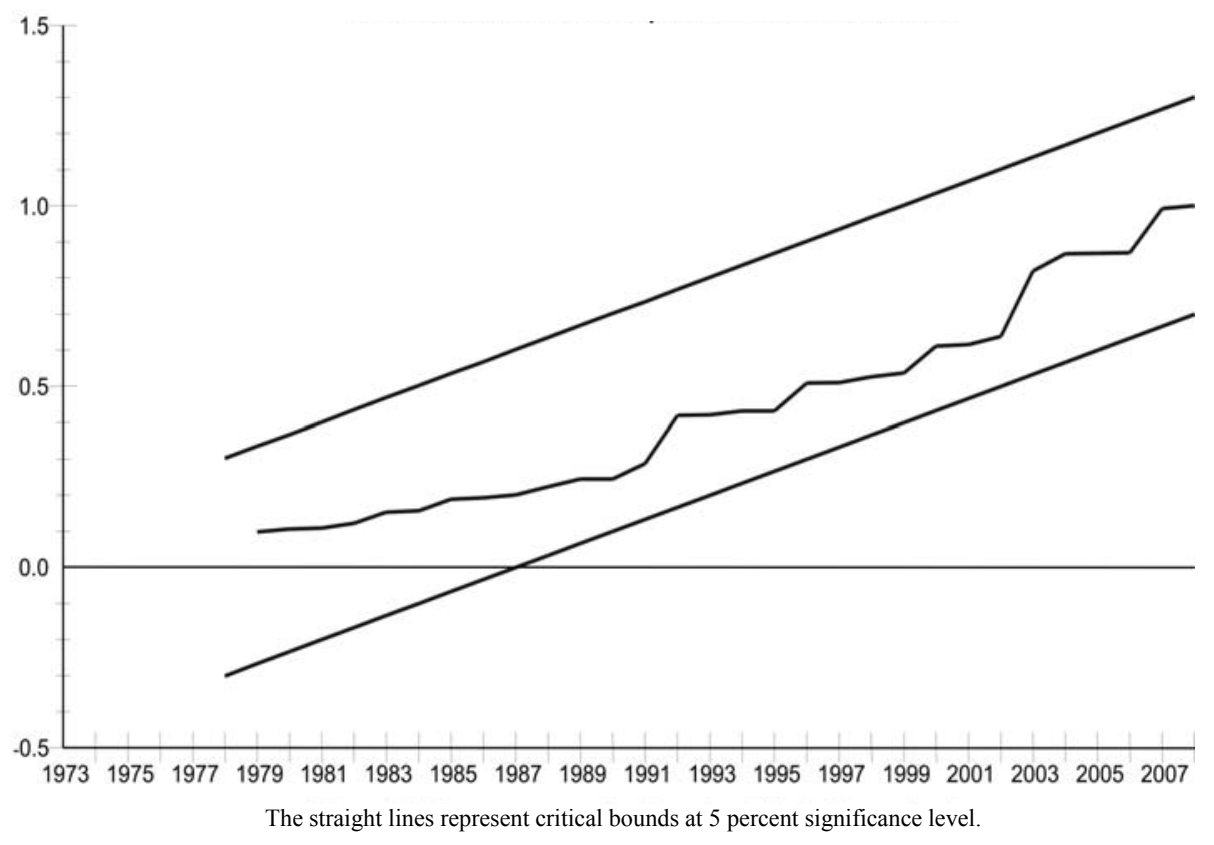

Fig. 2(a). Plot of Cumulative Sum of Recursive Residuals

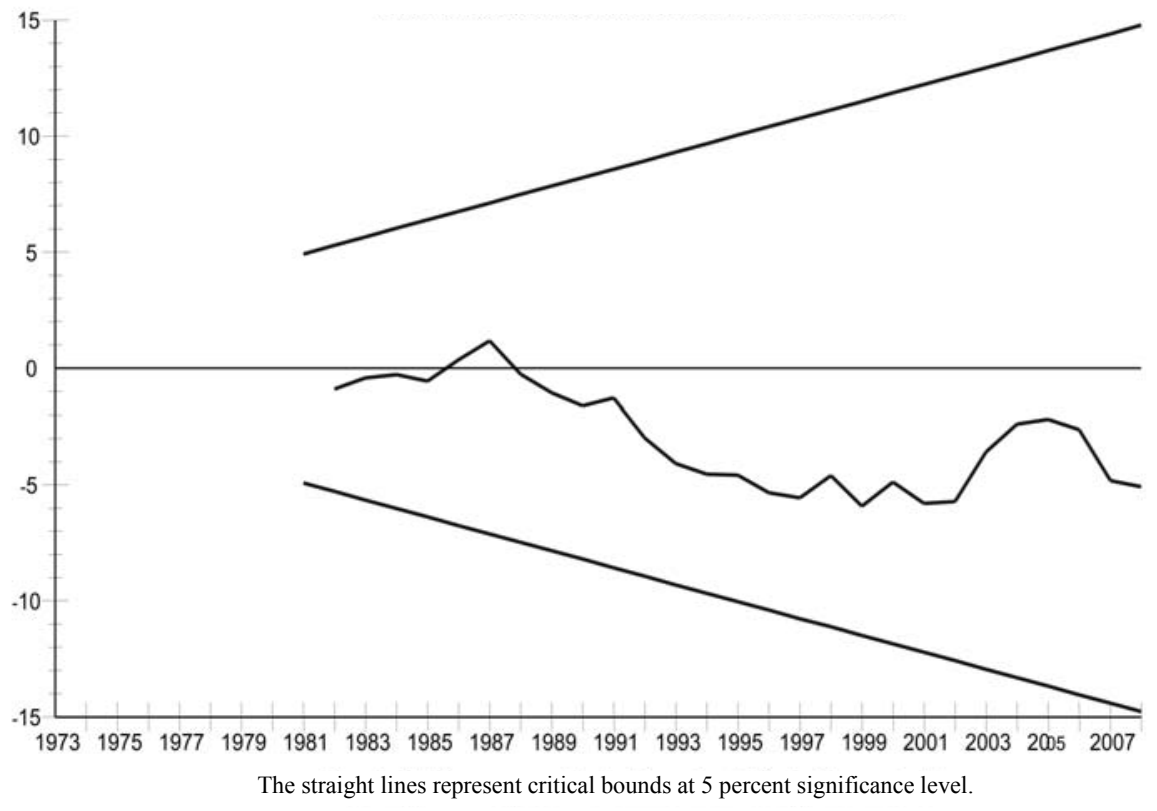


Fig. 2(b). Plot of Cumulative Sum of Squares of Recursive Residuals

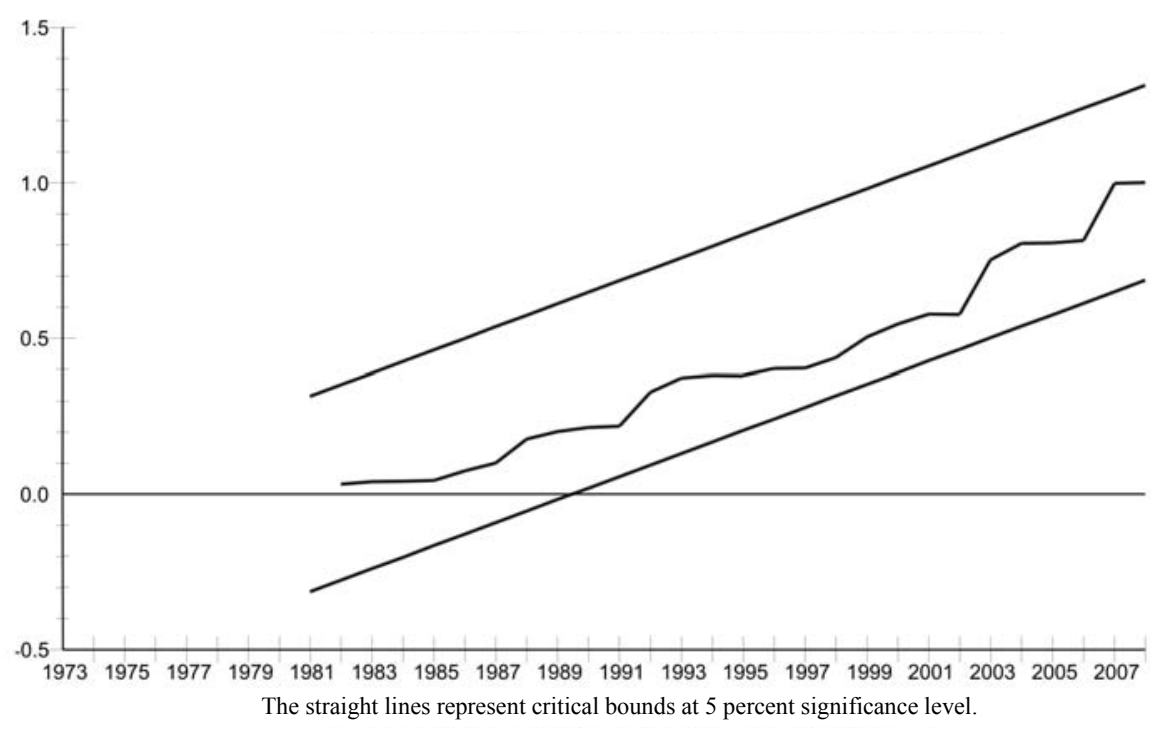

Once the stability and LR relationship have been established, the results of LR coefficients using ARDL approach are presented in Table 6.

Table 6

Estimated Long-run Coefficients Using the ARDL Approach and SBC (Dependent Variable $=\ln$ Real GDP $(Y))$

\begin{tabular}{lccccc}
\hline & \multicolumn{2}{c}{ ARDL $(1,0,1)$ without HD } & & \multicolumn{2}{c}{ ARDL $(1,2,0,1)$ with HD } \\
\cline { 2 - 3 } \cline { 5 - 6 } Regressor & Coefficient & t-ratio (P-value) & & Coefficient & t-ratio (P-value) \\
\hline $\ln$ PC & 1.0867 & $1.7069(0.098)$ & & 0.4179 & $3.3753(0.002)$ \\
$\ln$ RX & -0.3267 & $-0.5416(0.592)$ & & 0.0927 & $0.9940(0.329)$ \\
In HD & & & & $\mathbf{0 . 8 4 6 2}$ & $\mathbf{2 . 8 5 2 3}(\mathbf{0 . 0 0 8})$ \\
Constant & 5.66624 & $4.5700(0.000)$ & & 9.1634 & $6.6331(0.000)$ \\
\hline
\end{tabular}

The LR elasticity coefficients of PC and HD in ARDL $(1,2,0,1)$ model are positive and statistically significant, indicating that both PC and HD are enhancing economic growth in the LR. HD has the highest positive and significance effect among other explanatory variables on EGr in the LR. This is consistent with the findings of Emadzadeh, et al. (2000), Nili and Nafisi (2003), Mohamadi (2006), Dargahi and Gadiri (2003), and Komijani and Memernejad (2004). RX have positive but insignificant effect on EGr in the LR.

The next stage of analysis is based on error correction model (ECM). After examining LR relationships among variables, the SR dynamics of these variables can be determined by error correction representation of ARDL model based on Equation (4). ECM specification for ARDL $(1,2,0,1)$ model is reported in Table 7. 
Table 7

ECM Representation for Selected ARDL Model Based on SBC

(Dependent Variable $=\Delta$ ln Real GDP $(Y)$ )

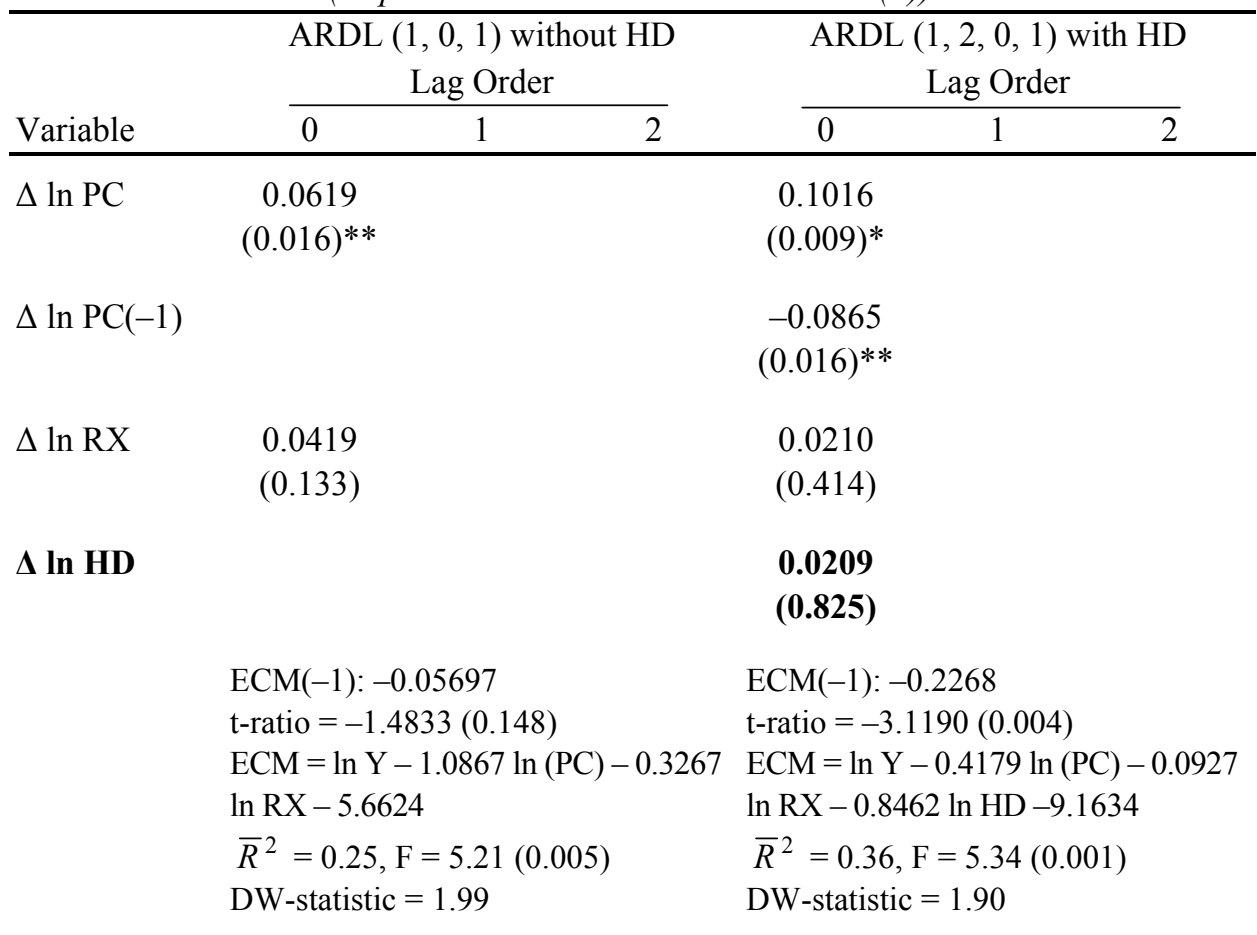

$\overline{\text { Values in parentheses are P-values, and }{ }^{*},{ }^{*},{ }^{* *} \text { indicate } 1 \text { percent, } 5 \text { percent and } 10 \text { percent level of }}$ significance respectively.

The coefficient of lagged error correction term reveals how much rapidly variable returns to equilibrium and it must be statistically significant with negative sign. The absolute value of $\operatorname{ECM}(-1)$ indicates speed of adjustment to return to equilibrium and the negative sign shows convergence in the SR dynamic model. The negative and highly significant sign of lagged error correction term $(\operatorname{ECM}(-1))$ is also a more efficient way of establishing cointegration and LR causality. The coefficient of $\operatorname{ECM}(-1)$ for ARDL $(1,2,0,1)$ in Table 7 is -0.227 and this means that in each period, 22.7 percent of shocks can be justified as a LR trend. 22.7 percent of the deviation from equilibrium is eliminated within one year. The small absolute value of coefficient of $\operatorname{ECM}(-1)$, i.e. 22.7 percent, implies that RGDP is not rapidly adjusted to changes in the LR equilibrium component. This coefficient of $E C_{t-1}$ in this model is negative and significant at 99 percent level of confidence. It implies that, in Pakistan, EGr, PC, exports and HD are cointegrated, which is not in line of results presented in Table 4 for cointegration. Moreover, the results presented in Table 7 refute any SR significant of the RX and HD in explaining real GDP. The significant effect of PC on EGr is found in the both SR and LR. The effect of HC is more pivotal in explaining real GDP than both RX and PC in LR as had been 
expected. So it is recommended that the Government of Pakistan should continue its quest for HC promotion policies. HC-based endogenous growth theory seems valid only in LR. The effect of RX on RGDP is positive both in the LR and SR but not statistically significant. This finding does not seem to support the validity of 'exportled growth hypothesis' in case of Pakistan. As a conclusion LR elasticity of PC, RX and HD on RGDP are found to be bigger and more significant than SR counterparts. Tables 5, 6 and 7 also reveal that with the inclusion of HDI as a measure of HD reduces the PC share in real GDP (i.e. from 109 percent to 42 percent in LR and from 6.2 percent to 1.5 percent in SR) and boosts up over all share of capital (both PC and HC) in determining real GDP in the LR (i.e. from 109 percent to 126.4 percent) whereas it improves the robustness of the regression model. The negative LR effect of RX on RGDP also became positive with the inclusion of HD variable. This finding justifies the inclusion of HD as a third variable in the model.

To assess Equation (5), concerning the effects of RGDP, HD, PC on RX, it was estimated by using ARDL approach. The results of dynamic ARDL $(1,1,0,0)$ of Model 2 are reported in Table 8.

Table 8

Dynamic ARDL Model: ARDL (1, 1, 0, 0) Based on SBC (Dependent Variable $=$ ln Real Exports $(R X)$ )

\begin{tabular}{lcc}
\hline Regressor & Coefficient & t-ratio (P-value) \\
\hline $\ln \mathrm{RX}(-1)$ & 0.55473 & $3.8810(0.001)$ \\
$\ln \mathrm{PC}$ & 0.50768 & $2.4015(0.032)$ \\
$\ln \mathrm{PC}(-1)$ & -0.59512 & $-3.1839(0.003)$ \\
$\ln \mathrm{Y}$ & 0.84767 & $2.0615(0.048)$ \\
$\ln \mathrm{HD}$ & -0.28173 & $-0.48380(0.632)$ \\
Constant & -6.0669 & $-1.3403(0.191)$ \\
\hline
\end{tabular}

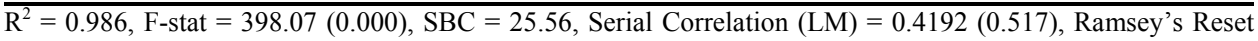
Test $=0.4214(0.516)$, Heteroscedasticity $(L M)=0.093(0.923)$, Normality $(L M)=1.5869(0.452)$.

The figures in parentheses are P-values.

The results of the dynamic ARDL $(1,1,0,0)$ model for RX presented in Table 8 support the hypothesis that both PC and RGDP are significant in the explanation of RX in Pakistan. The results in Table 8 also seem to support the 'growth-driven export hypothesis' in case of Pakistan. The results of CUSUM and CUSUM SQUARE tests exist within a 5 percent level showing the significant and stable SR and LR relation among the variables (Figure 3). 
Fig. 3(a). Plot of Cumulative Sum of Recursive Residuals

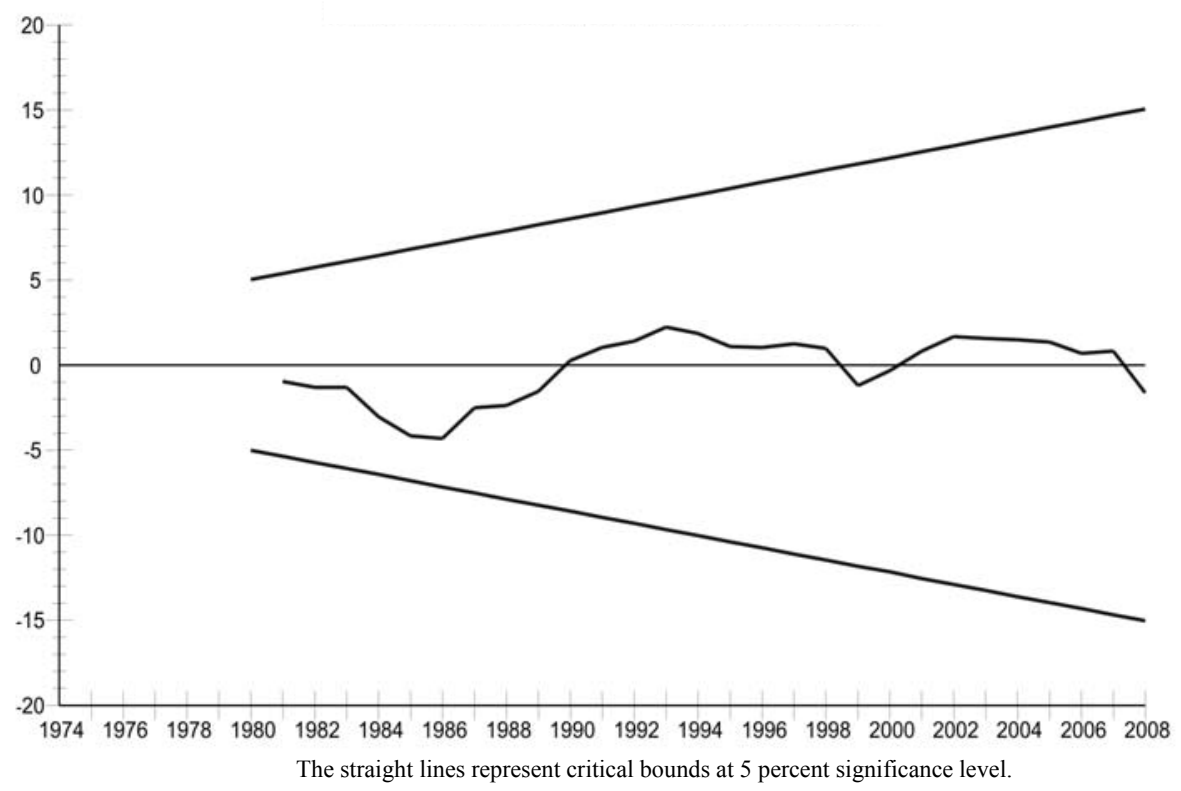

Fig. 3(b). Plot of Cumulative Sum of Squares of Recursive Residuals

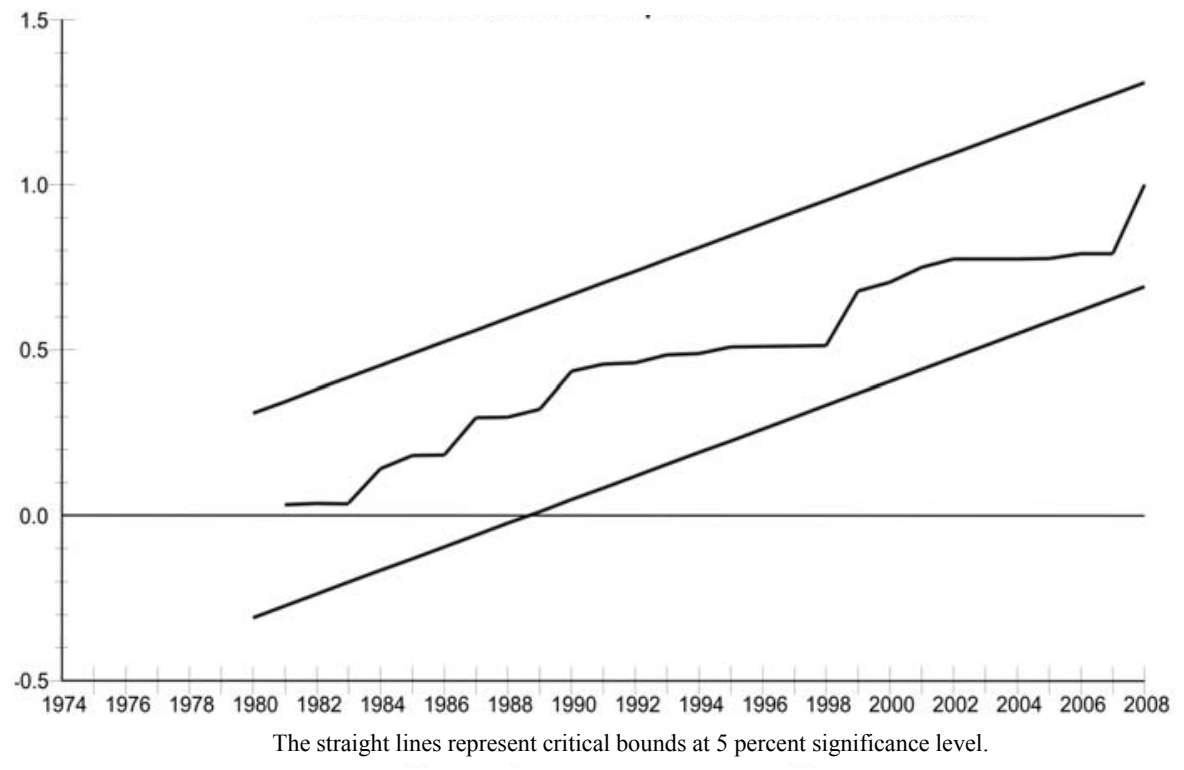

After examining the stability and establishing LR relationship, the results of LR coefficients using ARDL Model 2 for the variable RX are presented in Table 9. 
Table 9

Estimated Long-run Coefficients Using the ARDL Approach and SBC (Dependent Variable $=$ ln Real Exports $(R X)$ )

\begin{tabular}{lcc}
\hline Regressor & Coefficient & t-ratio (P-value) \\
\hline Ln PC & -0.1964 & $-0.4550(0.652)$ \\
$\ln \mathrm{Y}$ & 1.9037 & $2.4368(0.021)$ \\
$\ln \mathrm{HD}$ & -0.6327 & $-0.5058(0.617)$ \\
Constant & -13.6254 & $-1.5543(0.131)$ \\
\hline
\end{tabular}

The LR elasticity coefficient of RGDP in Table 9 is positive and statistically significant at 95 percent level of confidence, indicating that the RGDP will enhance RX in the LR. The LR elasticity coefficient of HD on RX is negative and highly insignificant. The SR dynamic coefficients of RGDP, PC and HD for RX can be determined by error correction representation of ARDL model based on Equation (5) by repeating the third stage of the model. Its results are reported in Table 10.

Table 10

ECM Representation for Selected ARDL Model Based on SBC (Dependent Variable $=\Delta$ ln Real Exports $(R X)$ )

\begin{tabular}{lcc}
\hline & \multicolumn{1}{c}{ Lag Order } \\
\cline { 2 - 3 } Variable & 0 & 1 \\
\hline$\Delta \ln \mathrm{PC}$ & $0.5077(0.023)$ & \\
$\Delta \ln \mathrm{Y}$ & $0.8477(0.048)$ & \\
$\Delta \ln \mathrm{HD}$ & $-0.2817(0.630)$ & \\
\hline $\mathrm{ECM}(-1):-0.4453$, t-ratio $=-3.1152(0.004)$. \\
$\mathrm{ECM}=\ln \mathrm{RX}+0.1964 \ln (\mathrm{PC})-1.9037 \ln (\mathrm{Y})+0.6327 \ln \mathrm{HD}+13.6254$. \\
$R^{2}=0.45, \mathrm{~F}=5.87(0.001), \mathrm{DW}-\mathrm{statistic}=1.67$. \\
Values in parentheses are P-values.
\end{tabular}

From Table 10, it is obvious that the $\operatorname{ECM}(-1)$ has a correct sign, i.e. negative and its coefficient is statistically significant. It implies that, in Pakistan, RX, PC, HD and EGr are cointegrated when real exports served as dependent variable. This result is not in line with the results in Table 4 for cointegration. The absolute value of coefficient of $\operatorname{ECM}(-1)$ in Table 10 is 0.445 and this implies that in each period, about 44.5 percent of shocks can be justified as LR trends. It also implies that 44.5 percent of the previous year's disequilibrium in RX from its equilibrium path will be corrected in the recent year. The positive and significant effect of real GDP on exports is supported in both the LR and the SR at 95 percent level of confidence. This supports the validity of 'growth-driven exports hypothesis' in Pakistan. Furthermore, long run elasticity of real GDP on RX is found bigger than its SR counterpart. This implies that the impact of increasing real GDP on RX is higher in the LR than in the SR. The highly insignificant and negative effect of HD on exports is found both in LR and SR dynamic models. This might be the outcome that exiting stock of knowledge and skill do not match with desired technology for enhancing RX. This also might be the result that large portion of Pakistan's exports still constituted primary and semi-manufactured commodities. 
To examine Equation (6), concerning the effect of RGDP, RX and PC on HD, it was estimated by using ARDL approach. The results of dynamic ARDL $(3,2,0,3)$ of model 3 are reported in Table 11.

\section{Table 11}

Dynamic ARDL Model: ARDL (3, 2, 0, 3) Based on $S B C$

(Dependent Variable $=\ln H D$ )

\begin{tabular}{lcc}
\hline Regressor & Coefficient & t-ratio (P-value) \\
\hline $\ln \mathrm{HD}(-1)$ & 0.2366 & $1.2969(0.208)$ \\
$\ln \mathrm{HD}(-2)$ & -0.2671 & $-1.7291(0.097)$ \\
$\ln \mathrm{HD}(-3)$ & 0.4711 & $3.4134(0.002)$ \\
$\ln \mathrm{PC}$ & -0.0864 & $-2.0035(0.057)$ \\
$\ln \mathrm{Y}$ & -0.2571 & $-1.0225(0.317)$ \\
$\ln \mathrm{Y}(-1)$ & 1.1483 & $3.1670(0.004)$ \\
$\ln \mathrm{Y}(-2)$ & -0.6199 & $-2.1844(0.039)$ \\
$\ln \mathrm{RX}$ & 0.0368 & $1.0020(0.327)$ \\
$\ln \mathrm{RX}(-1)$ & -0.0608 & $-1.2286(0.232)$ \\
$\ln \mathrm{RX}(-2)$ & -0.0970 & $-1.9959(0.052)$ \\
$\ln \mathrm{RX}(-3)$ & 0.1359 & $3.8987(0.001)$ \\
Constant & -0.9487 & $-1.1182(0.275)$ \\
\hline$R^{2}=0.993$, F-stat $=293.45(0.000)$, SBC $=74.09$, Serial Correlation (LM) $=1.1458(0.284)$, Ramsey's Reset \\
Test $=0.0129(0.910)$, Heteroscedasticity $(\mathrm{LM})=2.0053(0.157)$, Normality $(\mathrm{LM})=0.5458(0.761)$. \\
The figures in parentheses are P-values.
\end{tabular}

The results of the estimated dynamic ARDL $(3,2,0,3)$ model for HD presented in Table 11 indicate that lagged values of HD itself, lagged values of RGDP and lagged values of RX are helpful and significant in the explanation of HD. Since the results of CUSUM and CUSUM SQUARE tests proposed by Brown, et al. (1975) exist within a 5 percent level show the significant and stable relation among the variables under consideration (Figure 4). There is ample evidence of structural stability in the model.

Fig. 4(a). Plot of Cumulative Sum of Recursive Residuals

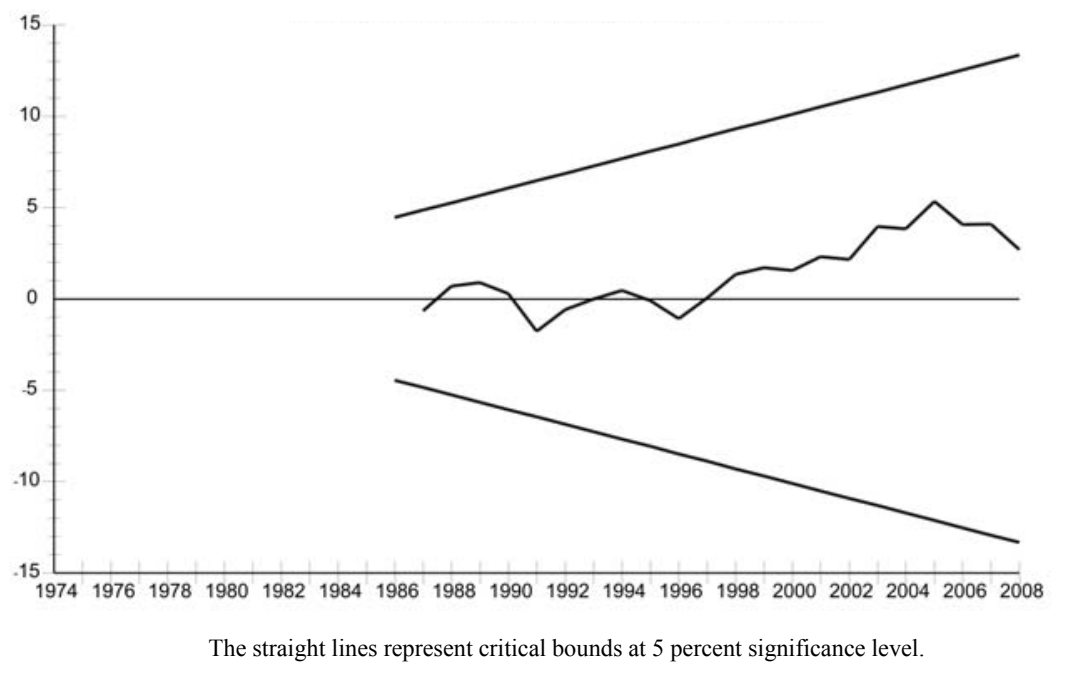


Fig. 4(b). Plot of Cumulative Sum of Squares of Recursive Residuals

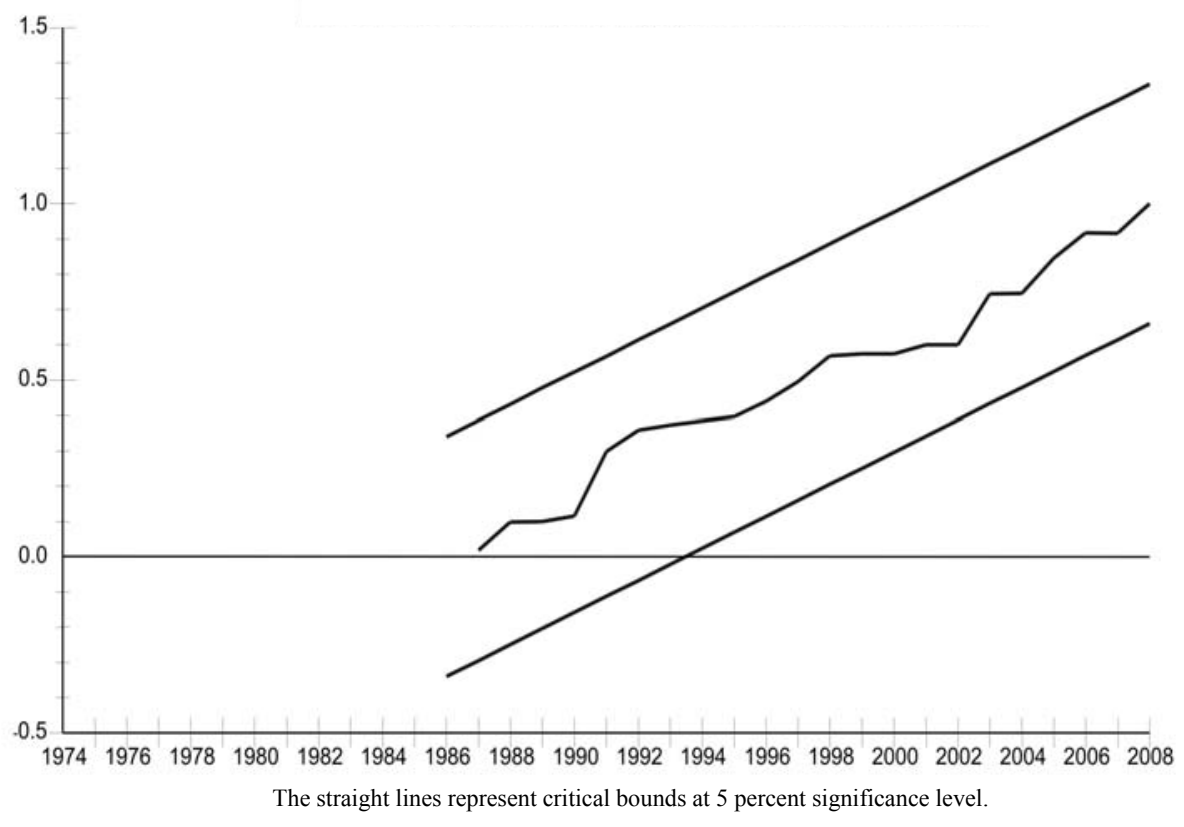

After having tested the stability and LR relationship among variables, the results of LR coefficients using ARDL approach are presented in Table 12 below.

\section{Table 12}

Estimated Long-run Coefficients Using the ARDL Approach Based on SBC (Dependent Variable $=\ln H D$ )

\begin{tabular}{lcc}
\hline Regressor & Coefficient & t-ratio (P-value) \\
\hline $\ln \mathrm{PC}$ & -0.1545 & $-1.66636(0.110)$ \\
$\ln \mathrm{Y}$ & 0.4849 & $4.2710(0.000)$ \\
$\ln \mathrm{RX}$ & 0.0267 & $0.2573(0.799)$ \\
Constant & -1.6957 & $-1.8653(0.075)$ \\
\hline
\end{tabular}

The LR elasticity coefficient of RGDP is positive and highly statistically significant, indicating that RGDP will enhance HD in the LR. The elasticity coefficient of $\mathrm{RX}$ is positive and highly insignificant.

After examining LR relationship among HD, RX and RGDP, the SR dynamics of these variables can be determined by error correction representation of ARDL model based on Equation (6). The results are reported below in Table 13. 
Table 13

ECM Representation for Selected ARDL Model Based on SBC (Dependent Variable $=\Delta \ln H D$ )

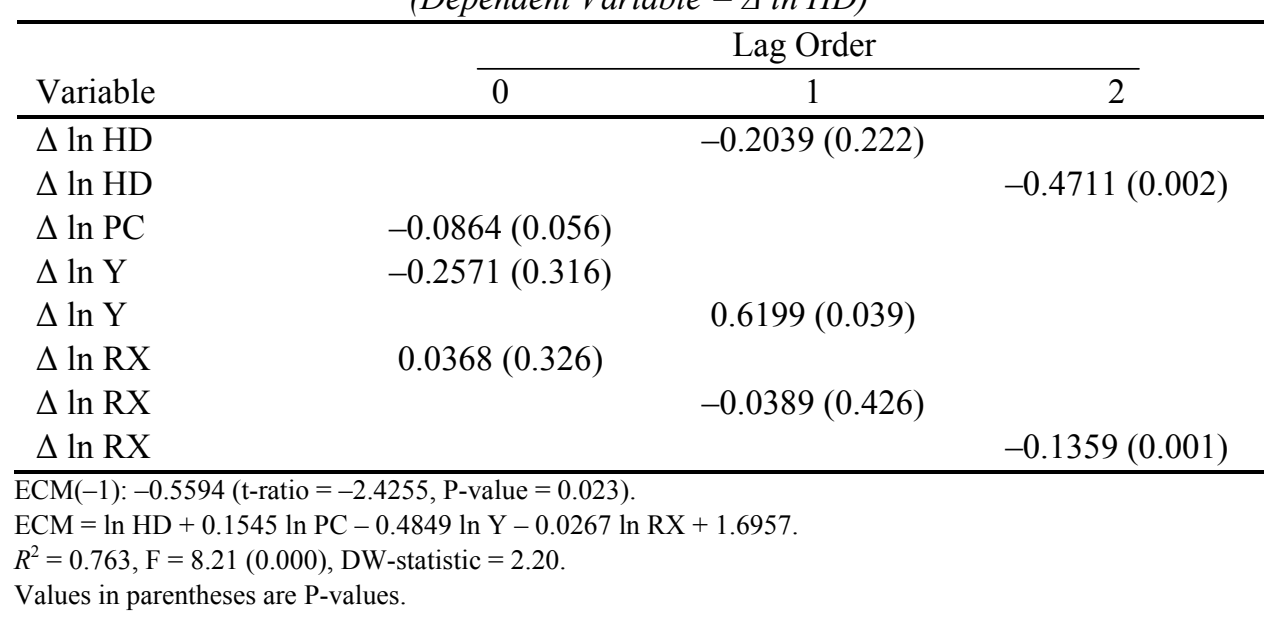

The absolute value of coefficient of $\operatorname{ECM}(-1)$ in Table 13 is 0.559 , indicating a moderate speed of adjustment to equilibrium following SR shocks. This also means that 55.9 percent of the disequilibrium caused by previous period shocks, converges back to equilibrium and this also means that in each period, 55.9 percent of shocks can be justified as a LR trend. The coefficient of $\mathrm{EC}_{\mathrm{t}-1}$ in the model is negative and significant at 97 percent level of confidence. It implies that, in Pakistan, exports, PC, EGr, and HC are cointegrated. This finding about cointegration among the variables, when HD is the dependent variable is in accordance with the results presented in Table 4 for cointegration. The positive and significant effect of real GDP on HD is supported both in LR (confidence at 99 percent) and SR (confidence at 96 percent). The effect of two period lagged RX on HD is negative and highly significant indicating the reverse trend and behaviour of both the labour force and exporters about improving their HC stock in the SR.

In short, the ARDL results indicate that (i) the inclusion of $\mathrm{HD}$ as an explanatory variable in addition to $\mathrm{PC}, \mathrm{RX}$ in augmented growth function raises the robustness of the model; (ii) cointegration among real GDP, PC, RX and HD raises their significance when HD serves as a dependent variable; (iii) RX do not support and promote both the real GDP and HD both in SR and LR; (iv) HD promotes real GDP only in the LR and at the same time it does not explain RX in Pakistan; and (v) real GDP proves itself to be a significant source of explaining and promoting both the RX and HD both in SR and LR.

\section{Diagnostic Tests}

Some other diagnostic tests were used for serial correlation, model specification, heteroskedasticity and conflict to normality that is based on a test of skewness and kurtosis of residuals. All the models satisfied and qualify all the above diagnostic tests. 


\section{Toda-Yamamoto Augmented Granger Causality Test}

The causal linkages among real GDP, PC, RX and HD are being investigated by following the Granger causality procedures adopted by Toda and Yamamoto (1995) and interpreted and further expanded by Rambaldi and Doran (1996) and Zapata and Rambaldi (1997). Zapata and Rambaldi (1997) argue that this test needs no prior knowledge of the cointegration among the variables and the usual lag selection scheme to the systems can still be applied in a case where there exists no cointegration or the rank conditions and stability are not satisfied "so long as the order of integration of the process does not exceed the true lag length of the model" [Toda and Yamamoto (1995), p. 225]. The attractiveness of applying Toda and Yamamoto (1995) technique to test Granger causality lies in its simplicity to apply and ability to overcome many a shortcomings of other alternative cumbersome econometric procedures such as developed by Toda and Phillips (1993) and Mosconi and Giannini (1992). Toda-Yamamoto Augmented Granger Causality Test applied Modified WALD test (MWALD) for restrictions on the parameters of a $\operatorname{VAR}(\mathrm{k})$, where $\mathrm{k}$ is the lag length in the system of equations. This test statistic follows a $\chi^{2}$-distribution when VAR $\left(k+d_{\max }\right)$ is estimated. Here, $d_{\max }$ shows the maximum order of integration likely to happen in the system of equations. Here, we utilise Seemingly Unrelated Regression (SUR) because it has been proved by Rambaldi and Doran (1996) that MWALD test for testing Granger causality can be easily applied by using SUR. One of the advantages of utilising SUR is that it also takes care of the possible simultaneity bias in the system of equations. One of the characteristics of VAR model is that it permits the researcher to test the direction of causality. Use of VAR can also overcome the problem of simultaneity bias. In VAR, all the variables are taken as endogenous variables.

To examine the causality between real GDP, PC, RX and HD, this study utilised the Toda-Yamamoto Augmented Granger Causality Test. The following system of equations is being estimated to investigate the Augmented Granger causality test:

$$
\begin{aligned}
& Y_{t}=\alpha_{1}+\sum_{i=1}^{3} \beta_{1 i} Y_{t-i}+\sum_{i=1}^{3} \gamma_{1 i} P C_{t-i}+u_{1 t} \quad \ldots \quad \ldots \quad \ldots \quad \ldots \\
& P C_{t}=\alpha_{2}+\sum_{i=1}^{3} \beta_{2 i} Y_{t-i}+\sum_{i=1}^{3} \gamma_{2 i} P C_{t-i}+u_{2 t} \quad \ldots \quad \ldots \quad \ldots \quad \ldots \\
& Y_{t}=\alpha_{3}+\sum_{i=1}^{3} \beta_{3 i} Y_{t-i}+\sum_{i=1}^{3} \gamma_{3 i} R X_{t-i}+u_{3 t} \quad \ldots \quad \ldots \quad \ldots \quad \ldots \\
& R X_{t}=\alpha_{4}+\sum_{i=1}^{3} \beta_{4 i} Y_{t-i}+\sum_{i=1}^{3} \gamma_{4 i} R X_{t-i}+u_{4 t} \quad \ldots \quad \ldots \quad \ldots \quad \ldots \quad \ldots \\
& Y_{t}=\alpha_{5}+\sum_{i=1}^{3} \beta_{5 i} Y_{t-i}+\sum_{i=1}^{3} \gamma_{5 i} H D_{t-i}+u_{5 t} \quad \ldots \quad \ldots \quad \ldots \quad \ldots \\
& H D_{t}=\alpha_{6}+\sum_{i=1}^{3} \beta_{6 i} Y_{t-i}+\sum_{i=1}^{3} \gamma_{6 i} H D_{t-i}+u_{6 t} \quad \ldots \quad \ldots \quad \ldots \quad \ldots
\end{aligned}
$$


The above three systems of two equations each is estimated by SUR method. To explore that PC does not Granger cause GDP, the null hypothesis will be $\mathrm{H}_{0}: \gamma_{1 i}=0$ where $\gamma_{1 i}$ are the coefficients of $P C_{t-i}, i=1,2,3\left(H_{0}: \gamma_{11}=\gamma_{12}=\gamma_{13}=0\right)$ in the first equation of the system. Likewise the other null hypothesis for second equation is $\mathrm{H}_{0}$ : $\beta_{2 i}$ $=0$ where $\beta_{2 i}$ are the coefficients of $G D P_{t-i}, i=1,2,3\left(H_{0}: \beta_{21}=\beta_{22}=\beta_{23}=0\right)$ that is the GDP does not Granger cause PC. This was carried out by means of a Wald test with the null hypothesis that the values of the estimated coefficients $\left(\beta_{2 i}\right.$ and $\left.\gamma_{2 i}\right)$ are zero. The other hypothesis for remaining system of two equations was also formulated in the same manner. The results of the Toda-Yamamoto test of augmented Granger causality are given in Table 14.

Table 14

Toda-Yamamoto Granger Causality Test

\begin{tabular}{|c|c|c|c|c|}
\hline \multirow[b]{2}{*}{ Equations } & \multirow[b]{2}{*}{ Null Hypothesis } & \multirow[b]{2}{*}{ Value } & \multicolumn{2}{|c|}{$\begin{array}{c}\text { Test Statistic } \\
\text { Wald test }\left(\chi^{2} \text {-statistic }\right)\end{array}$} \\
\hline & & & $\mathrm{df}$ & Prob. \\
\hline \multicolumn{5}{|c|}{ Bivariate-RGDP and Physical Capital } \\
\hline Equation 1 & PC does not Granger cause RGDP & 8.7588 & 1 & {$[.003]$ Reject $H_{0}$} \\
\hline Equation 2 & RGDP does not Granger cause PC & 12.7208 & 1 & [0.000] Reject $H_{0}$ \\
\hline \multicolumn{5}{|c|}{ Bivariate-RGDP and Exports } \\
\hline Equation 3 & Exports does not Granger cause RGDP & .72878 & 1 & [.393] Cannot Reject $\mathrm{H}_{0}$ \\
\hline Equation 4 & RGDP does not Granger cause Exports & 26.5535 & 1 & [0.000] Reject $H_{0}$ \\
\hline \multicolumn{5}{|c|}{ Bivariate-RGDP and Human Development (HD) } \\
\hline Equation 5 & HD does not Granger cause RGDP & 1.4697 & 1 & {$[.225]$ Cannot Reject $\mathrm{H}_{0}$} \\
\hline Equation 6 & RGDP does not Granger cause HD & 16.1701 & 1 & [0.000] Reject $H_{0}$ \\
\hline \multicolumn{5}{|c|}{ Trivariate-RGDP, Exports and HD } \\
\hline Equation 7 & Export does not Granger cause RGDP & .034072 & 1 & [.854]Cannot Reject $\mathrm{H}_{0}$ \\
\hline Equation $7 \mathrm{a}$ & HD does not Granger cause RGDP & .73780 & 1 & {$[.390]$ Cannot Reject $\mathrm{H}_{0}$} \\
\hline Equation 8 & RGDP does not Granger cause Exports & 13.0664 & 1 & {$[.000]$ Reject $H_{0}$} \\
\hline Equation 9 & RGDP does not Granger cause HD & 1.4891 & 1 & [.222]Cannot Reject $\mathrm{H}_{0}$ \\
\hline Equation $8 \mathrm{a}$ & HD does not Granger cause Exports & 1.9722 & 1 & {$[.160]$ Cannot Reject $\mathrm{H}_{0}$} \\
\hline Equation 9a & Exports does not Granger cause HD & .53383 & 1 & [.465]Cannot Reject $\mathrm{H}_{0}$ \\
\hline \multicolumn{5}{|c|}{ Tetravariate-RGDP, Exports, HD, and PC } \\
\hline Equation 10 & Export does not Granger cause RGDP & .47336 & 1 & [.491] Cannot Reject $\mathrm{H}_{0}$ \\
\hline Equation $10 \mathrm{a}$ & HD does not Granger cause RGDP & .098718 & 1 & [.753] Cannot Reject $\mathrm{H}_{0}$ \\
\hline Equation $10 \mathrm{~b}$ & PC does not Granger cause RGDP & 8.0928 & 1 & [.004] Reject $H_{0}$ \\
\hline Equation $10 \mathrm{c}$ & RGDP does not Granger cause Exports & 13.5116 & 1 & [0.000] Reject $H_{0}$ \\
\hline Equation 11 & HD does not Granger cause Exports & 1.4224 & 1 & [.233] Cannot Reject $\mathrm{H}_{0}$ \\
\hline Equation 11a & PC does not Granger cause Exports & .62814 & 1 & [.428] Cannot Reject $\mathrm{H}_{0}$ \\
\hline Equation $11 \mathrm{~b}$ & RGDP does not Granger cause HD & 1.0588 & 1 & [.303]Cannot Reject $\mathrm{H}_{0}$ \\
\hline Equation $11 \mathrm{c}$ & Exports does not Granger cause HD & .31531 & 1 & [.574] Cannot Reject $\mathrm{H}_{0}$ \\
\hline Equation 12 & PC does not Granger cause HD & .53811 & 1 & [.463] Cannot Reject $\mathrm{H}_{0}$ \\
\hline Equation $12 \mathrm{a}$ & RGDP does not Granger cause PC & .11842 & 1 & [.731] Cannot Reject $\mathrm{H}_{0}$ \\
\hline Equation $12 \mathrm{~b}$ & Exports does not Granger cause PC & 1.7246 & 1 & [.189] Cannot Reject $\mathrm{H}_{0}$ \\
\hline Equation $12 \mathrm{c}$ & HD does not Granger cause PC & 1.9909 & 1 & [0.158] Cannot Reject $\mathrm{H}_{0}$ \\
\hline
\end{tabular}


The statistical results of bivariate causality indicate that the null hypothesis of no Granger causality between PC and real GDP is rejected at 1 percent level of significance. Similar hypothesis regarding no Granger causality between real GDP and PC is rejected at 1 percent level of significance. These results support the presence of bidirectional causality between real GDP and PC. To test causality between real exports (RX) and real GDP (RGDP), the system of Equations (11) and (12) has been estimated by SUR. The null hypothesis that RX do not Granger cause RGDP cannot be rejected at 95 percent level of confidence. On the other hand, the hypothesis that RGDP does not Granger cause exports can be rejected at 95 percent level of confidence. It was found that there is one way causality running from RGDP to RX in a bivariate case. The causal flow from real output to real export is termed as 'growth-driven exports'. Exports are thus not seen as the significant source of EGr in Pakistan. Similarly another bivariate analysis between RGDP and HD (Equations 13 and 14) also indicates a unidirectional causality running only from RGDP to HD. In conclusion, in case of bivariate analysis, 'export-led growth hypothesis' is not seen to be valid while bivariate results support the validity of 'growthdriven hypothesis'. Human capital-based endogenous growth theory does not seem to be valid in case of bivariate causality analysis.

Now moving to trivariate system of equations (Equations (15), (16) and (17)) to analyse the Augmented Granger Causality for the variables RX, real GDP and HD. As found above in bivariate analysis, RX do not Granger cause RGDP at 95 percent level of confidence, whereas RGDP does Granger cause RX at 99 percent level of confidence in case of trivariate analysis. Similarly no Granger causality between HD and RGDP and between HD and RX was established in trivariate analysis. In conclusion, in case of trivariate analysis, 'export-led growth hypothesis' is not valid whereas 'growth-driven exports hypothesis' found valid. The 'human based-endogenous growth theory' still found not valid in case of trivariate analysis.

To test the tetravariate causality between RGDP, RX, HD and PC, again use of SUR was made. It was found that RGDP does Granger cause RX while exports do not Granger cause real GDP. It was also found that PC does Granger cause RGDP.

Regarding causality running from HD to real GDP in all cases (bivariate, trivariate and tetravariate analyses) the null hypothesis that HD does not Granger cause real GDP cannot be rejected. Thus, it can be concluded that 'human capital based-endogenous growth theory' is not valid in case of Pakistan. In sum, only 'growth-driven exports hypothesis' was found valid in case of Pakistan.

The statistical results also reveal that causality running from real GDP to HD does Granger cause only in bivariate analysis. This can be explained as: when people get richer because of EGr they prefer to send their children for higher education, knowledge and skills instead of sending them in the labour market. Similarly, because of increase in EGr, R\&D expenditure will also grow. Finally, the statistical results do not support the presence of Granger causality between HD and RX. Thus, it could be the result of mismatch between existing $\mathrm{HC}$ stock and the required $\mathrm{HC}$ to produce exportables.

$$
\begin{aligned}
& Y_{t}=\alpha_{7}+\sum_{i=1}^{3} \beta_{7 i} Y_{t-i}+\sum_{i=1}^{3} \lambda_{7 i} H D_{t-i}+\sum_{i=1}^{3} \gamma_{7 i} R X_{t-i}+u_{7 t} \quad \ldots \\
& R X_{t}=\alpha_{8}+\sum_{i=1}^{3} \beta_{8 i} Y_{t-i}+\sum_{i=1}^{3} \lambda_{8 i} H D_{t-i}+\sum_{i=1}^{3} \gamma_{8 i} R X_{t-i}+u_{8 t} \quad \ldots
\end{aligned}
$$




$$
\begin{aligned}
& H D_{t}=\alpha_{9}+\sum_{i=1}^{3} \beta_{9 i} Y_{t-i}+\sum_{i=1}^{3} \lambda_{9 i} H D_{t-i}+\sum_{i=1}^{3} \gamma_{9 i} R X_{t-i}+u_{9 t} \quad \ldots \\
& Y_{t}=\alpha_{10}+\sum_{i=1}^{3} \beta_{10 i} Y_{t-i}+\sum_{i=1}^{3} \gamma_{10 i} P C_{t-i}+\sum_{i=1}^{3} \lambda_{10 i} H D_{t-i}+\sum_{i=1}^{3} \delta_{10 i} R X_{t-i}+u_{10 t} \ldots \\
& R X_{t}=\alpha_{11}+\sum_{i=1}^{3} \beta_{11 i} Y_{t-i}+\sum_{i=1}^{3} \gamma_{11 i} P C_{t-i}+\sum_{i=1}^{3} \lambda_{11 i} H D_{t-i}+\sum_{i=1}^{3} \delta_{11 i} R X_{t-i}+u_{11 t} \ldots \\
& H D_{t}=\alpha_{12}+\sum_{i=1}^{3} \beta_{12 i} Y_{t-i}+\sum_{i=1}^{3} \gamma_{12 i} P C_{t-i}+\sum_{i=1}^{3} \lambda_{12 i} H D_{t-i}+\sum_{i=1}^{3} \delta_{12 i} R X_{t-i}+u_{12 t} \ldots
\end{aligned}
$$

From the results of the ARDL models and Augmented Granger Causality tests, the qualitative results of the study are summarised in Table 15.

Table 15

Comparison of Results of ARDL Approach and Augmented Granger Causality Tests Regarding Validity of Hypotheses of the Study

\begin{tabular}{lccccc}
\hline \multirow{2}{*}{$\begin{array}{l}\text { Validity of Hypotheses at 95 percent } \\
\text { Level of Confidence }\end{array}$} & ARDL Approach Results & \multicolumn{3}{c}{ Toda-Yamamoto Granger Causality } \\
\cline { 3 - 5 } & Bivariate & Trivariate & Tetravariate & Overall \\
\hline Export-led Growth Hypothesis & Yes & No & No & No & No \\
Growth-driven Exports Hypothesis & Yes in LR, & & Yes & Yes & Yes \\
Human Based Endo-genous & No in SR & No & No & No & No \\
Growth Theory & & & &
\end{tabular}

'Export-led growth hypothesis' cannot be supported at 95 percent level of confidence in case of Pakistan. However, the sign of the regression coefficients of real GDP in all causality tests remained positive. This materialised situation could be the result of trade composition and trade policy of Pakistan. Although, Pakistan's trade has significantly shifted from primary and semi-manufactured goods and services to manufactured goods, but exports share of the country in GDP remained almost the same. The results of this study are consistent with those of Akbar and Naqvi (2000), Ahmed, et al. (2000) and Afzal, Rehman, and Rehman (2008).

On the other hand, the null hypothesis that real GDP does not Granger cause RX is rejected in case of Pakistan. This finding is consistent with Doganlar and Fisunoglu (1999) and Afzal, Rehman and Rehman(2008). In addition, the ARDL results presented in Tables 8, 9 and 10 do support the 'growth-driven export hypothesis'. Thus, it can be concluded that 'growth-driven hypothesis' is valid in case of Pakistan. This finding about growth-driven hypothesis is consistent with Afzal, Rehman, and Rehman (2008). According to ARDL model 1, HD promotes real GDP only in the LR but Granger causality analysis do not support the human capital-based endogenous growth theory in case of Pakistan. Thus, it can be concluded that 'human capital-based endogenous growth theory' is not valid in case of Pakistan. 


\section{CONCLUSION AND RECOMMENDATIONS}

The ARDL results indicate that the inclusion of human development as an explanatory variable in addition to physical capital, real exports in augmented growth function raises the robustness of the model. The ARDL Approach to Cointegration results show cointegration between economic growth, physical capital, real exports and human development when human development is taken as dependent variables. The statistical results and their analysis support the 'growth-driven exports hypothesis'. However, the hypotheses of export-led growth and human capital based endogenous growth are not found valid for Pakistan. The invalidity of export-led growth is also supported by the existing data on exports to GDP ratio [Pakistan Economic Survey (2008-09), p. 61]. It might be because of the two main reasons: firstly, the result of brain drains of highly skilled labour force and, secondly, the outcome of mismatch between existing human capital stock and required human capital stock to produce and enhance real GDP. Real GDP is found to be a significant source of explaining and promoting both the real exports and human development both in short-run and long-run, while human capital accumulations and real exports do not seem to accelerate real GDP in the short-run. It is, therefore, recommended that Government of Pakistan should allocate more resources for the promotion of human capital. There is a need for serious effort on the part of the Government to revise its export promotion policies. The goal of export promotion can be achieved by restructuring export composition and by exploring new markets. The 'export-led growth hypothesis', 'growth-driven exports hypothesis' and 'human capital-based endogenous growth theory' may further be tested and generalised in case of Pakistan by including other economic and non-economic variables like foreign direct investment, terms of trade, imports, financial development, energy, debt and debt servicing and political turmoil etc.

\section{REFERENCES}

Afzal, Muhammad (2006) Causality between Exports, World Income and Economic Growth in Pakistan. International Economic Journal 20:1, 63-77.

Afzal, Muhammad, Hafeez ur Rehman, and Jamshaid ur Rehman (2008) Causal Nexus between Economic Growth, Export and External Debt Servicing: The Case of Pakistan. Retrieved December 14, 2009 from http://www.pide.org.pk/PSDE/pdf/ 32.pdf.

Ahmad, J. and S. Harnhirun (1995) Unit Roots and Cointegration in Estimating Causality between Exports and Economic Growth: Empirical Evidence from the ASEAN Countries. Economics Letters 49, 329-334.

Ahmad, Jaleel (2001) Causality between Exports and Economic Growth: What do the Econometric Studies Tell Us? Pacific Economic Review 6:1, 147-67.

Ahmad, Jaleel, Somchai Harnhirun, and Jing Yang (1997) Exports and Economic Growth in the ASEAN Countries: Cointegration and Causality Tests. International Review of Economics and Business 44:2, p. 419.

Ahmed, J. and A. C. C. Kwan (1991) Causality between Exports and Economic Growth. Economic Letters 37, 243-248. 
Ahmed, Qazi Massod, M. Sabihuddin Butt, and Shaista Alam (2000) Economic Growth, Export and External Debt Causality: The Case of Asian Countries. The Pakistan Development Review 34:4, 591-08.

Akbar, M. and Z. F. Naqvi (2000) Export Diversification and Structural Dynamic Growth Process: The Case of Pakistan. The Pakistan Development Review 39:4, 573-589.

Alderman, H., J. Behrman, S. Khan, D. Ross, and R. Sabot (1996a) The Income Gap In Cognitive Skills in Rural Pakistan. Economic Development and Cultural Change 44.

Alderman, H., J. Behrman, S. Khan, D. Ross, and R. Sabot (1996b) The Returns To Endogenous Human Capital In Pakistan's Rural Wage Market. Oxford Bulletin of Economics and Statistics.

Al-Yousif, Yousif Khalifa (1997) Exports and Economic Growth: Some Empirical Evidence from Arab Gulf Countries. Applied Economics 29, 693-697.

Amoateng, K. and B. Amoako-Adu (1996) Economic Growth, Export and External Debt Causality: The Case of African Countries. Applied Economics 28, 21-27.

Asteriou, D. and G. M. Agiomirgianakis (2001) Human Capital and Economic Growth: Time Series Evidence from Greece. Journal of Policy Modeling 23:5, 481-489.

Awokuse, Titus O. (2003) Is the Export-Led Growth Hypothesis Valid for Canada? Canadian Journal of Economics 36: 1, 126-136.

Awokuse, Titus O. (2005) Exports, Economic Growth and Causality in Korea. Applied Economics Letters 12:11, 693-96.

Bahmani-Oskooee, M. and A. Nasir (2004) ARDL Approach to Test the Productivity Bias Hypothesis. Review of Development Econ. J. 8, 483-488.

Bahmani-Oskooee, M. and T. J. Brooks (1999) Bilateral J Curve between US and Her Trading Partners. Welwirtschaftliches Archiv, Band 135, Heft I, 56-165.

Bahmani-Oskooee, M., H. Mohtadi, and G. Shabsigh (1991) Exports, Growth and Causality In Ldcs: A Re-Examination. Journal of Development Economics 36, 405415.

Balasubarmanyam, V. N., M. Salisu and D. Sapsford (1996) Foreign Direct Investment and Growth in EP and IS Countries. The Economic Journal 106, 92-105.

Banerjee, A., J. W. Dolado, Galbraith, and D. F. Hendry (1993) Cointegration, Error Correction and the Econometrics Analysis of Non-Stationary Data. Oxford: Oxford University Press.

Bannerjee, A., J. W. Dolado, and R. Mestre (1998) Error-Correction Mechanism Tests for Cointegration in Single Equation Framework. Journal of Time Series Analysis 19, 267-283.

Behrman, J. R. and B. L. Wolfe (1987a) How Does Mother's Schooling Affect the Family's Health Nutrition Medical Care Usage and Household? Journal of Econometrics 36.

Behrman, J. R. and B. L. Wolfe (1987b) Investments in Schooling in Two Generations in Pre-Revolutionary Nicaragua: The Roles of Family Background and School Supply. Journal of Development Economics 27.

Birdsall, N. (1985) Public Inputs and Child Schooling in Brazil. Journal of Development Economics 18.

Brown, R. L., J. Durbin and J. M. Evans (1975) Techniques for Testing the Constancy of Regression Relationships Over Time. Journal of the Royal Statistical Society, Series B, 37, 149-192. 
Chen, Shyh-Wei (2007) Exactly What Is the Link between Export and Growth in Taiwan? New Evidence from the Granger Causality Test. Economics Bulletin 6:7, 1-10.

Chow, P. C. Y. (1987) Causality between Export Growth and Industrial Development: Empirical Evidence from the NICS. Journal of Development Economics 26:1, 55-63.

Chuang, Y.C. (2000) Human Capital, Exports and Economic Growth: A Causality Analysis for Taiwan, 1952-1995. Review of International Economics 8:4, 712-720.

Dargahi, J. (2003) Analyses of Economic Growth Elements in Iran. Journal of Research in Economics p. 26.

De Meulemeester, J. L. and D. Rochat (1995) A Causality Analysis of the Link between Higher Education and Development. Economics of Education Review 14:4, 351-361.

Demirhan, Erdal and Selcuk Akcay (2005) The Causality Relationship between Export Growth and Economic Growth: Empirical Evidence from Selected MENA Countries. Iktisat Isletme Ve Finans May, 20:230, 124-131.

Deolalikar, A. B. (1993) Gender Differences in the Returns to Schooling and School Enrollment Rates in Indonesia. Journal of Human Resources 28.

Din, Musleh ud (2004) Exports, Imports, and Economic Growth in South Asia: Evidence Using a Multivariate Time-Series Framework. The Pakistan Development Review 43:2, 105-124.

Doganlar, Murat and Mahir Fisunoglu (1999) Causality between Exports and Economic Growth in Asian Countries. Yapi Kredi Economic Review 10:1, 3-11.

Emadzadeh, et al. (2000) The Role of Human Capital in Economic Growth. Journal of Planning and Development 5:1, 21.

Engle, R. F. and C. W. J. Granger (1987) Co-integration and Error Correction: Representation, Estimation, and Testing. Econometrica 55, 251-76.

Gould, D. and R. Ruffin (1995) Human Capital, Trade and Economic Growth. Weltwirtschaftliches Archiv 131:3, 425-445.

Graves, Philip E. and J. A. Holman (1995) Korean Exports Economic Growth: An Econometric Reassessment. Journal of Economic Development 20:2, 45-56.

Gregory, A. W. and B. E. Hansen (1996) Residual-Based Tests for Cointegration in Models with Regime Shifts. Journal of Econometrics 70, 99-126.

Grossman, G. and E. Helpman (1991) Innovation and Growth in the Global Economy. Cambridge, MA: MIT Press.

Hansen, H. and J. Rand (2006) On the Causal Links between FDI and Growth in Developing Countries. The World Economy 29:1, 21-41.

Hatemi, J. Abdulnasser (2002) Export Performance and Economic Growth Nexus in Japan: A Bootstrap Approach. Japan and the World Economy 14:1, 25-33.

Hatemi, J. Abdulnasser and Manuchehr Irandoust (2000) Export Performance and Economic Growth Causality: An Empirical Analysis. Atlantic Economic Journal 28:4, 412-426.

Heller, P. and R. Porter (1978) Exports and Growth: An Empirical Investigation. Journal of Development Studies 5:2, 191-193.

Helpman, E. and P. Krugman (1990) Market Structure and Foreign Trade. Cambridge MA: MIT Press.

Hsiao, M. C. W. (1987) Tests of Causality and Exogeneity between Exports and Economic Growth: The Case of the Asian NICs. Journal of Economic Development 12, 143-159. 
In, F. and C. Doucouliagos (1997) Human Capital Formation and US Economic Growth: A Causality Analysis. Applied Economics Letters 4:5, 329-331.

Islam, Muhammed N. (1998) Export Expansion and Economic Growth: Testing For Cointegration and Causality. Applied-Economics 30:3, 415-425.

Johansen, S. (1988) Statistical Analysis of Cointegration Vectors. Journal of Economic Dynamics and Control 12, 231-254.

Johansen, S. (1991) Estimation And Hypothesis Testing of Co-Integration Vectors in Gaussian Vector Autoregressive Models. Econometrica 59,1551-1580.

Johansen, S. and K. Juselius (1990), Maximum Likelihood Estimation and Inference on Cointegration with Applications to the Demand for Money. Oxford Bulletin of Economics and Statistics 52, 169-210.

Jones, Jonathan D. (1989) A Comparison of Lag-length Selection Techniques in Tests of Granger Causality between Money Growth and Inflation: Evidence for the US, 195986. Applied Economics 21, 809-822.

Jordaan, André C. and Joel Hinaunye Eita (2007) Testing the Export-led growth Hypothesis for Botswana: A Causality Analysis. University of Pretoria, Department of Economics. (Working Papers 2007-20).

Judson, R. (2002) Measuring Human Capital Like Physical Capital: What Does it Tell Us? Bulletin of Economic Research 54, 209-231.

Jung, W. S. and P. J. Marshall (1985) Exports, Growth and Causality in Developing Countries. Journal of Development Economics 18:2, 1-12.

Khalid, Ahmed M. and Bay Teck Cheng (1997) Imports, Exports and Economic Growth: Cointegration and Causality Tests for Singapore. Singapore Economic Review, October, 42:2, 32-39.

Khan, S., W. D. Shaw, and F. Hussain (1991) Causality between Literacy and Labour Productivity in Pakistan. Economics of Education Review 10:3, 245-251.

Kim, J. (1998) Economic Analysis of Foreign Education and Students Abroad. Journal of Development Economics 56:2, 337-356.

King, E. M. and L. A. Lillard (1987) Education Policy and Schooling Attainment in Malaysia and the Philippines. Economics of Education Review 6.

Kohpaiboon, A. (2004) Foreign Trade Regime and FDI-growth Nexus: A Case Study of Thailand. Australian National University. (Working Paper).

Komijani and Memernejad (2004) Impotence of Human Capital and R\&D in Economic Growth of Iran. Journal of Research in Economics 31.

Konya, L. (2006) Exports and Growth: Granger Causality Analysis on OECD Countries with a Panel Approach. Economic Modeling 23, 978-992.

Kovacic, Zlatko J. and Djordje Djukic (1991) Export Expansion and Economic Growth in Yugoslavia: Some Empirical Evidence. Economic Analysis and Workers' Management 25:2, 95-113.

Kremers, J. J. M., Neil R. Ericsson, and Juan J. Dolado (1992) The Power of Cointegration Tests. Oxford Bulletin of Economics and Statistics 54, 325-343.

Kwan, A. C. C. and J. Cotsomotis (1991) Economic Growth and Expanding Export Sector: China 1952-1985. International Economic Review 5, 105-117.

Lee, D. W. and T. H. Lee (1995) Human Capital and Economic Growth: Tests based on International Evaluation of Educational Achievement. Economic Letters 47, 219-225. 
Lee, Daniel Y. and Ming Shiun Pan (2000) On Exports and Economic Growth in East Asian Countries: Linear and Nonlinear Causality Analyses. Pennsylvania Economic Review Fall 9:2, 66-78.

Liu, X., C. Wang and Y. Wei (2001) Causal Links between Foreign Direct Investment and Trade in China. China Economic Review 12:2-3, 190-202.

Liu, X., H. Song and P. Romilly (1997) An Empirical Investigation of the Causal Relationship between Openness and Economic Growth in China. Applied Economics 29:12, 1679-1686.

Liu, X., P. Burridge and P. J. N. Sinclair (2002) Relationships between Economic Growth, Foreign Direct Investment and Trade: Evidence from China. Applied Economics 34:11, 1433-1440.

Lucas, R. (1988) On the Mechanics of Economic Development. Journal of Monetary Economics 22, 3-42.

MacKinnon, J. G. (1996) Numerical Distribution Functions for Unit Root and Cointegration Tests. Journal of Applied Econometrics 11, 601-618.

Mah, Jai S. (2005) Export Expansion, Economic Growth and Causality in China. Applied Economics Letters 12:2, 105-107.

Mansouri, B. (2005) The Interactive Impact of FDI and Trade Openness on Economic Growth: Evidence from Morocco. Paper presented on the 12th Economic Research Forum (ERF) Conf., Cairo.

Marin, D. (1992) Is the Export-led Growth Hypothesis Valid for Industrialised Countries? The Review of Economics and Statistics 74, 678-688.

Mohamadi, A. (2006) Role of Education in Iran Economic Growth-Fars Province. Education 22:4, 57-84.

Mosconi, R. and C. Giannini (1992) No-causality in Cointegrated Systems: Representation, Estimation and Testing. Oxford Bulletin of Economics and Statistics 54, 399-417.

Narayan, P. K. (2005) The Saving and Investment Nexus for China: Evidence from Cointegration Tests. Applied Economics 37, 1979-1990.

Narayan, P. K. and R. Smyth (2004a) Temporal Causality between Human Capital and Real Income in Cointegrated VAR Processes, Empirical Evidence from China, 19601999. International Journal of Business and Economics 3:1, 1-11.

Narayan, Paresh Kumar and Russell Smyth (2004b) Temporal Causality and the Dynamics of Exports, Human Capital and Real Income in China. International Journal of Applied Economics 1;1, 24-45.

$\mathrm{Ng}$, S. and P. Perron (2001) Lag Length Selection and the Construction of Unit Root Tests with Good Size and Power. Econometrica 69, 1519-1554.

Nili, M. and S. H. Nafisi (2003) Relationship between Human Capital and Economic Growth. Quarterly Journal of Economic Researches of Iran, p. 17.

Omisakin, Ohusegun A. (2009) Export-led Growth Hypothesis: Further Econometric Evidence from Nigeria. Pakistan Journal of Social Sciences 6:4, 219-223.

Onchoke, S. N. and F. In (1994) An Empirical Investigation of LR Relationship between Export Revenues and Economic Growth in the South Pacific Island Nations. The Singapore Economic Review 38:2, 213-228.

Pacific Island Countries. Economic Papers (Economic Society of Australia). 
Pakistan, Government of (Various Issues) Pakistan Economic Survey. Islamabad: Finance Division, Economic Advisor's Wing.

Perron, P. (1989) The Great Crash: The Oil Price Shock and the Unit Root Hypothesis. Econometrica 57, 1361-1401.

Perron, P. (1997) Further Evidence on Breaking Trend Functions in Macroeconomic Variables. Econometrica 80, 355-385.

Pesaran, M. H. and B. Pesaran (1997) Working with Microfit 4.0: Interactive Econometric Analysis. Oxford: Oxford University Press.

Pesaran, M. H. and Y. Shin (1995) An Autoregressive Distributed Lag Modeling Approach to Cointegration Analysis. In S. Storm, A. Holly and P. Diamond (ed.) Centennial Volume of Ranger Frisch. Cambridge: Cambridge University Press.

Pesaran, M. H. and Y. Shin (1999) An Autoregressive Distributed Lag Modeling Approach to Cointegration Analysis. In S. Strom (ed.) Econometrics and Economic Theory in the 20th Century: The Ragnar Frisch Centennial Symposium. Cambridge: Cambridge University Press.

Pesaran, M. H., Y. Shin and R. J. Smith (1996) Testing for the Existence of a Long-run Relationship. Department of Applied Economics, University of Cambridge, Cambridge. (DAE Working Paper No. 9622).

Pesaran, M. H., Y. Shin and R. J. Smith (2001) Bounds Testing Approaches to the Analysis of Level Relationships. Journal of Applied Econometrics 16, 289-326.

Pissarides, C. (1997) Learning by Trading and the Returns to Human Capital in Developing Countries. World Bank Economic Review 11:1, 17-32.

Rambaldi, A. N. and H.E. Doran (1996) Testing for Granger Non-causality in Cointegrated Systems Made Easy. Department of Econometrics, University of New England. (Working Papers in Econometrics and Applied Statistics No. 88, pp. 1-22).

Ramiret, A., G. Ranis and F. Steward (1997) Economic Growth and Human Development. Economic Growth Centre, Yale University (Centre Discussion Paper No. 787).

Ranis, G., F. Stewart and A. Ramirez (2000) Economic Growth and Human Development. World Development 28: 2, 197-219.

Rebelo, Sergio T. (1991) Long-run Policy Analysis and Long-run Growth. Journal of Political Economy 99:3, 500-521.

Reppas, P. A. and D. K. Christopoulos (2005) The Export-output Growth Nexus: Evidence from African and Asian Countries. Journal of Policy Modeling, 27, 929940.

Riddell, R., M. Robinson, J. deConinck, A. Muir, and S. White (1995) Nongovernmental Organisations and Rural Poverty Alleviation. New York: Oxford University Press.

Romer, P. (1987) Endogenous Technical Change. Journal of Political Economy 89, 71-102.

Romer, P. (1990) Human Capital and Growth: Theory and Evidence. Carnegie-Rochester Conference Series on Public Policy 32, 251-285.

Romer, Paul M. (1986) Increasing Returns and Long-run Growth. Journal of Political Economy 94:5, 1002-1037.

Saikkonen, Pentti and Helmut Lutkepohl (2000) Testing for the Cointegrating Rank of a VAR Process with Structural Shifts. Journal of Business and Economic Statistics (American Statistical Association) 18:4, 451-464. 
Sezgin, Selami and Tulide Yildirim (2002) The Demand for Turkish Defense Expenditure, Defense and Peace Economies. Taylor and Francis Journals 13:2.

Shan, J. and F. Sun (1995) On the Export-led Growth Hypothesis for the Little Dragons: An Empirical Reinvestigation. Applied Economic Journal 26:4, 353-369.

Shan, J. and F. Sun (1998) On the Export-led Growth Hypothesis: The Econometric Evidence from China. Applied Economics Journal 30, 1055-1065.

Shan, J. and G. G. Tian (1998) Causality between Exports and Economic Growth: The Empirical Evidence from Shanghai. Australian Economic Papers 37:2, 195-202.

Sharma, S. C., M. Norris, and D. W. W. Cheung (1991) Exports and Economic Growth in Industrialised Countries. Applied Economics Journal 23, 697-708.

Shirazi, Nasim Shah and Turkhan Ali Abdul Manap (2004) Exports and Economic Growth Nexus: The Case of Pakistan. The Pakistan Development Review 43:4, 563579.

Stock, J. H. and M. Watson (1993) A Simple Estimator of Cointegrating Vectors in Higher Order Integrated Systems. Econometrica 61, 783-820.

Stock, J. H. and M. W. Watson (1988) Testing for Common Trend. Journal of the American Statistical Association 83, 1097-1107.

Stokey, N. (1996) Free Trade, Factor Returns and Factor Accumulation. Journal of Economic Growth 1:4, 255-271.

Thornton, J. (1996) Cointegration, Causality and Export-led Growth in Mexico, 18951992. Economic Letters 50, 413-416.

Toda, H. Y. and P.C. B. Phillips (1993) Vector Autoregressions and Causality. Econometrica 61, 1367-1393.

Toda, H. Y. and T. Yamamoto (1995) Statistical Inference in Vector Autoregressive with Possible Integrated Processes. Journal of Econometrics 66, 225-250.

Turner, P. (2006) Response Surfaces for an F-test for Cointegration. Applied Economics Letters 13, 479-482.

UNDP (Various Issues) Human Development Report. New York: Oxford University Press.

Vohra, Rubina (2001) Export and Economic Growth: Further Time Series Evidence from Less-developed Countries. International Advances in Economic Research 7:3, 345350 .

Wernerheim, C. M. (2000) Cointegration and Causality in the Exports-GDP Nexus: The Post-War Evidence for Canada. Empirical Economics 25, 111-125.

Xu, Z. (1996) On the Causality between Export Growth and GDP Growth: An Empirical Reinvestigation. Review of International Economics 4, 172-184.

Zapata, H. O. and A. N. Rambaldi (1997) Monte Carlo Evidence on Cointegration and Causation. Oxford Bulletin of Economics and Statistics 59, 285-298. 


\section{Comments}

The paper titled 'A Dynamic Analysis of the Relationship among Human Development, Exports and Economic Growth in Pakistan' examines linkages among these three variables using latest econometric techniques. Specifically it tests three hypotheses; export-led growth hypothesis, human capital-based endogenous growth hypothesis and growth-driven export hypothesis. The theoretical construct of this paper is derived from endogenous growth theory which clearly supports second hypothesis and to some extent the first one. However, results of this paper reject the first two hypotheses and accept only the third one. So, there seems to be some contradiction of theory and results that needs to be explained in more detail.

Also recommendations of authors that government should allocate more resources for the development of human capital and government should revive export promotion schemes do not fit with the results of this paper. Similarly, their conclusion that invalidity of export-led growth hypothesis is due to brain drain and mismatch of existing and desired human capital is not based on data and analysis used in this paper.

Quaid-i-Azam University,

M. Mazhar Iqbal

Islamabad. 